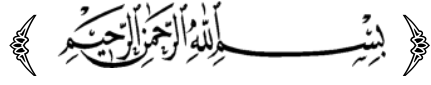

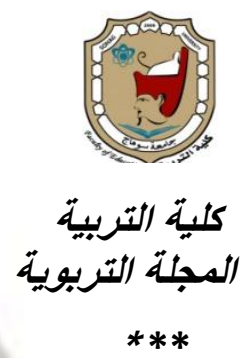

واقع تطبيق هضاهين إدارة المعرفة في إدارة تعليم الطائف وعلاقته بالتهيز المؤسسي هن وجهة نظر القيادات العاملة بها

$$
\text { | - (إعداد }
$$

أ أ فهل حميل محمد الثقفي

باحث ماجستير في القيادة التربوية

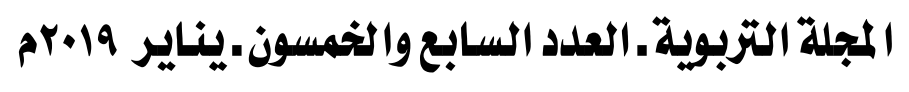

Print:(ISSN 1687-2649) Online:(ISSN 2536-9091) 
thack

هدفت الدراسة إلى الكشف عن واقع تطبيق مضامين إدارة المعرفة في إدارة تعليم الطائف وعلاقته بالتميز المؤسسي من وجهة نظر القيادات العاملة بها، ولتحقيق أهداف الدراسة تم اتباع المنهج الوصفي بصورته المسحية، كما تم اختيار عينة عشوائية طبقية من القيادات الوسطى والتتفيذية بلغ عددها (ع §؟) قائداً، وأخرى مسحية من القيادات العليا،

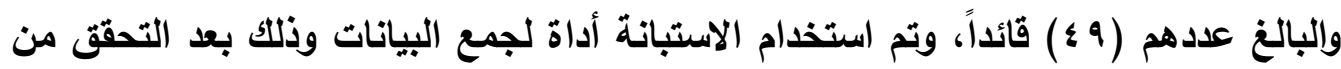
صدقها وثباتها، ومن ثمَّ تطبيقها على عينة الدراسة، وتوصلت الدراسة إلى أن الدرجة الكلية لتقدير أفراد عينة الدراسة لتطبيق إدارة المعرفة كانت (متوسطة)، فيما وجدت فروق ذات ذات آتهات دلالة إحصائية عند مستوى الدلالة (0.05 0 ( $)$ في الارجة الكلية وأبعاد المحور الأول تعزى لمتفيري الموقع القيادي لصالح القيادات العليا والمؤهل العلمي لصالح المؤهل العلمي الأعلى، كما حازت الدرجة الكلية لتقدير عينة الدراسة لتحقيق التميز المؤسسي على درجة

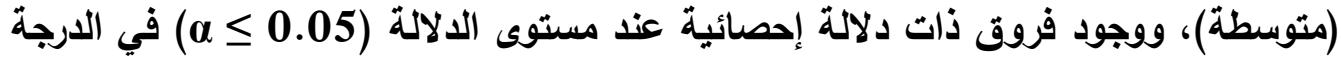
الكلية وأبعاد المحور الثاني تعزى لمتغيري الموقع القيادي لصالح القيادات العليا والمؤهل

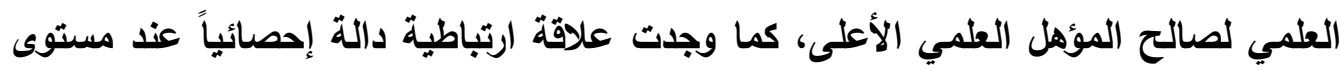

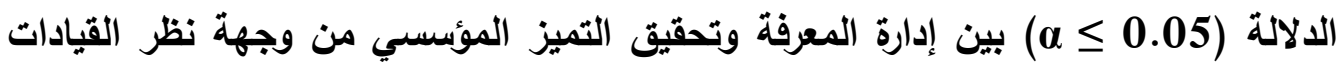


The study aimed to identify The Reality of Applying the Contents of Knowledge Administration in Taif Education Management and its Relation to Organizational Excellence from the leaders' Point of View, To achieve objectives of the study were followed descriptive approach with survey image. A random sample of 344 from the middle and executive leaders, and a survey sample consisted of $\mathbf{4 9}$ form senior leaders were also selected, the questionnaire was used as a Tool for data collection, and verify the validity and reliability, and then applied to a sample of basic study. The study found that the total score of the members of the study sample, from the educational leaders working in Taif management, to the degree of application of knowledge administration was (medium), while statistically significant differences were found at the level of significance ( $\alpha$ $\leq 0.05$ ) in the total score and the dimensions of the first axis The overall rank for the senior leadership and the scientific qualification for the highest scientific qualification was also obtained. The overall score of the sample was estimated to achieve the institutional excellence on a medium degree. There were also statistically significant differences at the level of significance $(\alpha \leq 0.05)$ For variables In addition, there was a significant correlation between the knowledge management and the achievement of institutional excellence from the point of view of educational leaders. 


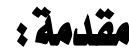

شهذ العالم في العقود الأخيرة تطورات سريعة ومتلاحقة في مختلف المجالات، والتي كان من أبرزها التحول ندو اقتصاد المعرفة، هذا الاقتصاد الذي أصبحت فيه المعرفة مورداً حيوياً في عمليات الإنتاج يفوق غيره من الموارد أهية وجدوى، وهو الأمر الذي يتطلب توجيه الجهود نحو حسن إدارتها وتفعيلها بشكل أكثر فاعلية.

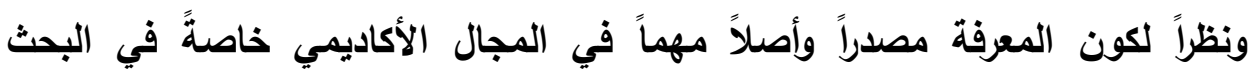

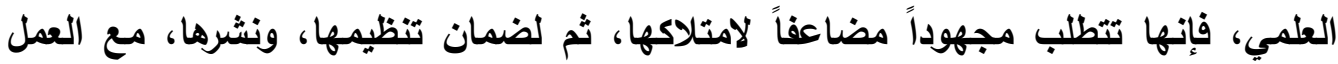
على تجويدها، وتوظيفها بشكل مناسب في عمليات اتخاذ القرار، باعتبارها قاعدة معرفية

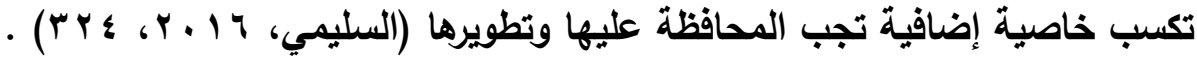

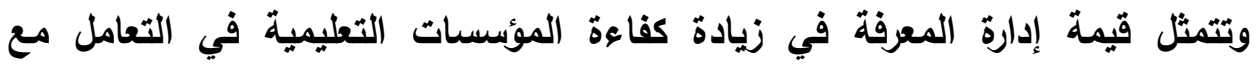

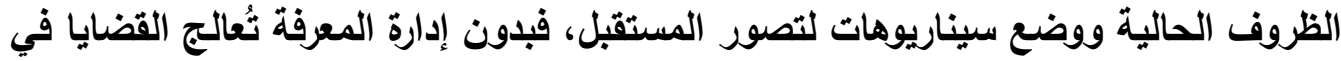

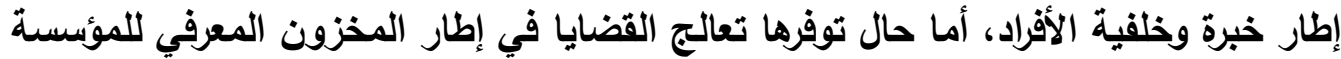

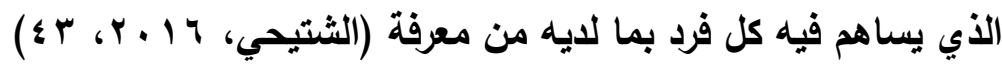
لذا فإن إدارة المعرفة أصبحت ضرورة ملحة، وهذا ما يشكل تحدٍ كبير للمؤسسات التعليمية، ويفرض عليها أن تحدث نقلة نوعية في إدارة المعرفة، وتبني خططها على هذا

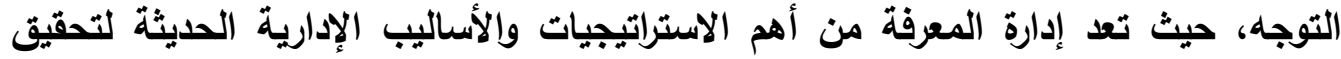

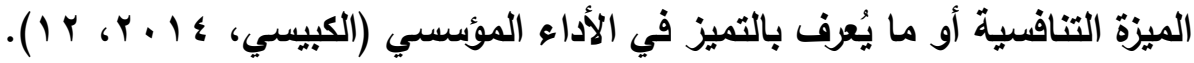
ولتحقيق هذا التميز المؤسسي، ظهز توجه بحثي يتمثل في ضرورة القيام بعمليات إعادة وتأهيل القوى العاملة بالمؤسسات التعليمية وتدريبها، وكذلك "القيام بتجميع المعرفة فئة

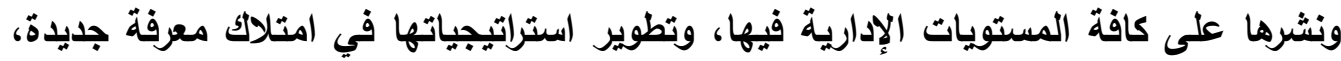
وتوظيف المعرفة التي تمتلكها بأقصى ما يمكن من الكفاءة والفاعلية وصولاً إلى مرحلة التميز

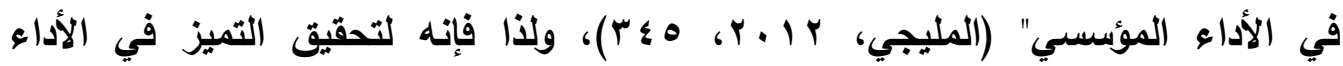

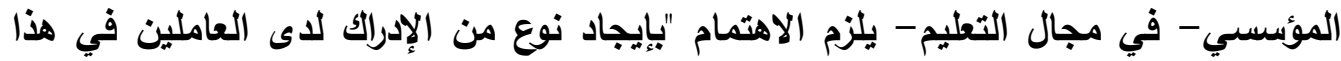

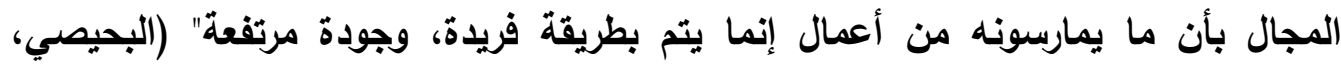


وهذا ما يشير إلى أن تحقيق التميز المؤسسي يتطلب "إحداث تغيير جذري في المناخ

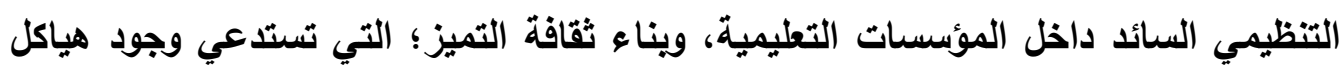

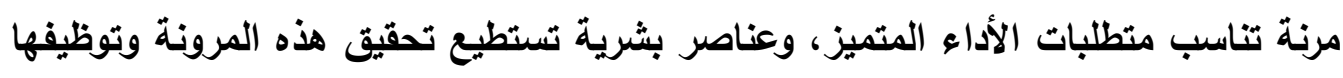

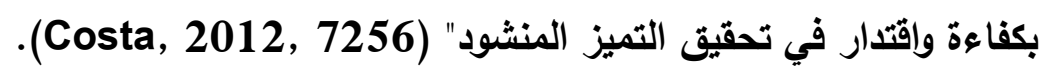

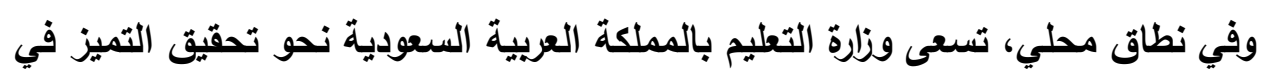

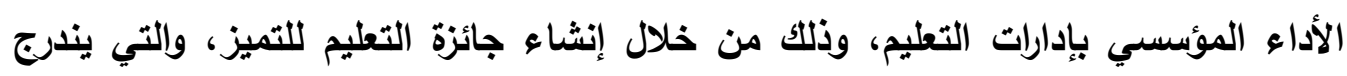

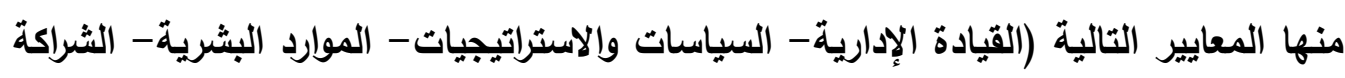

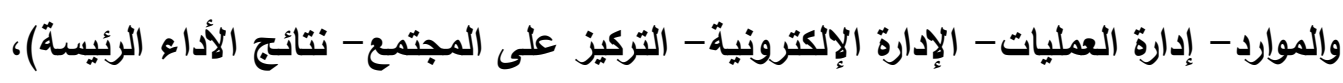

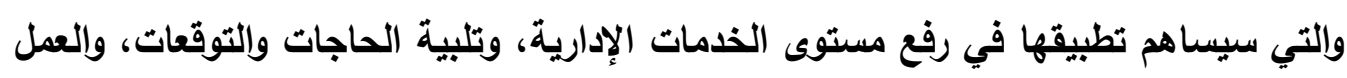

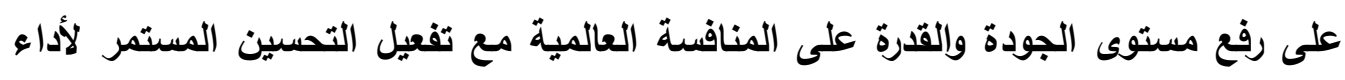

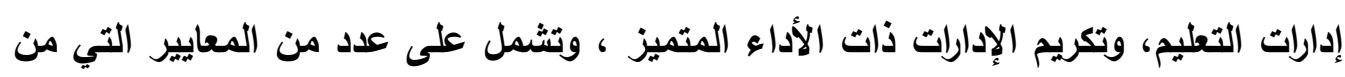

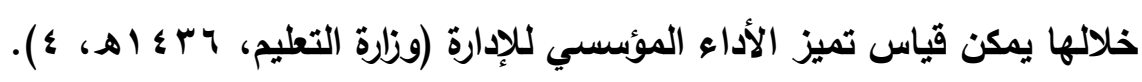

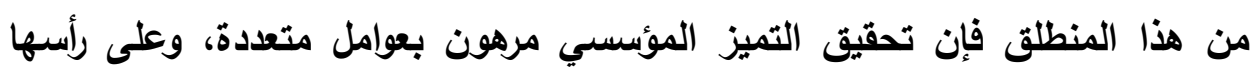

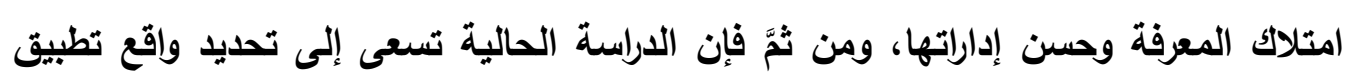

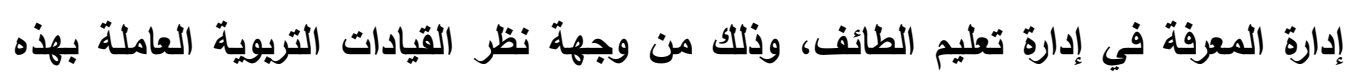
الإدارة، وإنعكاسات هذا الواقع على تحقيق التميز المؤسسي بها.

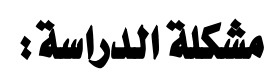

نظراً لتعاظم دور إدارة المعرفة وأهميتها أصبح التوجه الآن منصباً حول إدارة المعرفة

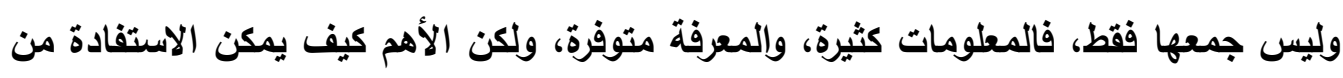

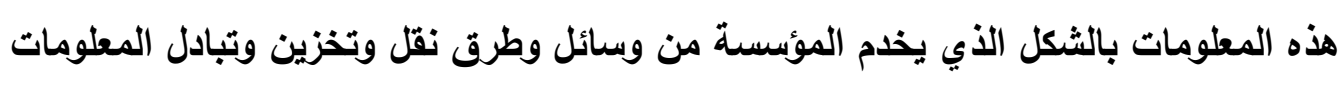

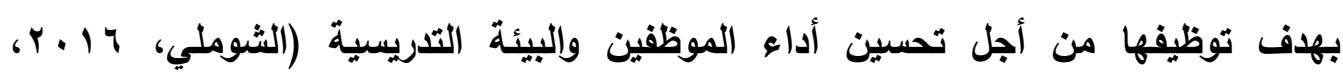
. 1 (1)

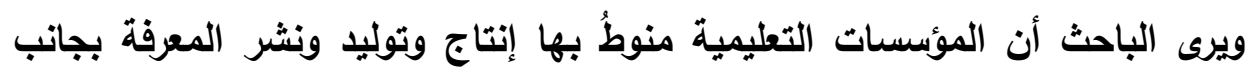

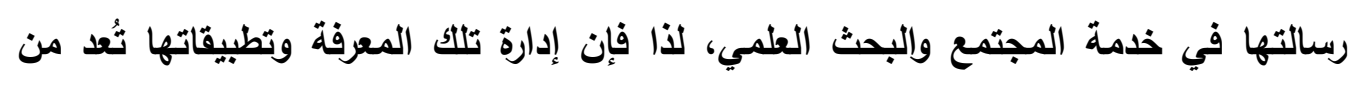
الجوانب المهمة التي تستدعي الاهتمام بها، والتركيز في تطبيقها، خاصة في ظل فل التحولات التهات 
الأخيرة التي تثهاها المملكة العربية السعودية، والروئية الجديدة التي تسعى إلى تحقيقها،

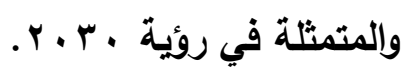

وعلى الرغم من الجهود التي تبذلها وزارة التعليم بالمملكة العربية السعودية في تطوير

نظامها التريوي لمواكبة المتغيرات المعاصرة، فإن مؤشرات تكشف عن وجود فجوة حقيقية بين باتين ما هو موجود، ويين ما هو مرغوب مستقبلاً لجعل المملكة في مصاف الدول المتقدمة علميًا

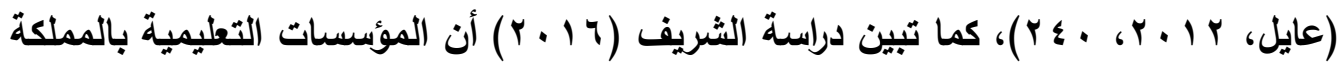
العربية السعودية لا تزال بعيدة عن التحولات الحادثة في عالم المعرفة، وهو الأمر الذي لهي يتطلب ضرورة تحقيق إدارة واعية للمعرفة لتحقيق الميزة التنافسية لهذه المؤسسات. ومع حداثة الاهتمام بمتغير "إدارة المعرفة" في المنظومة التعليمية، تبين للباحث- في حدود علمه- ندرة الدراسات التي سعت نحو تناول هذا المتغير في مؤسسات التعليم العام بالمملكة العربية السعودية، ويالتالي وجود قصور في تحديد العوامل المسهمة في تحقيق

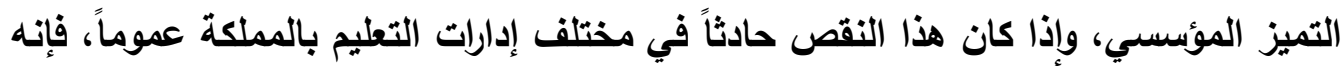
تتزايد الحاجة إلى دراسته في محافظة الطائف- محل عمل الباحث- تحديداً كونها من أكبر الإدارات التعليمية على مستوى المملكة العربية السعودية وفق المؤشرات الدالة على إمكانية تحقيق الجودة بها، وهو ما أكدته دراسة القثامي (ع بـ أهـ). فإن هذا ما أوجد الإحساس لديه بمشكلة الدراسة الحالية، والتي يمكن تحديد أبعادها في الكثف عن واقع تطبيق مضامين إدارة المعرفة في إدارة التعليم بالطائف من وجهة نظر القيادات العاملة بها وعلاقته بالتميز المؤسسي.

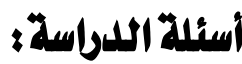

استناداً إلى تحديد جوانب مشكلة الدراسة، فإن الدراسة الحالية تسعى إلى الإجابة عن

الأسئلة الآتية:

(1) ما واقع تطبيق إدارة المعرفة بإدارة التعليم بالطائف من وجهة نظر القيادات التريوية العاملة بها؟

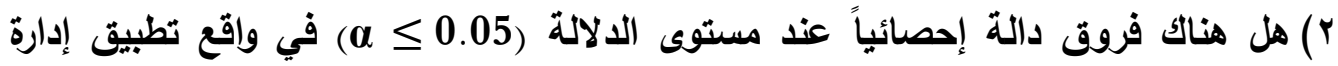
المعرفة في إدارة تعليم الطائف تُعزى إلى اختلاف عينة الدراسة في مواقعها القيادية 
(القيادات العليا- القيادات الوسطى - القيادات التفيذية)، والمؤهل العلمي (بكالوريوس -

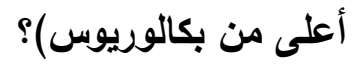

r) ما درجة تحقيق التميز المؤسسي بإدارة التعليم بالطائف من وجهة نظر القيادات التربوية العاملة بها؟

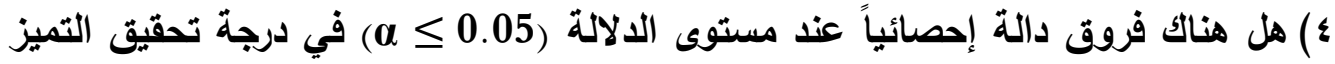
المؤسسي بإدارة تعليم الطائف تُعزى إلى اختلاف عينة الدراسة في مواقعها القيادية (القيادات العليا- القيادات الوسطى - القيادات التفيذية)، والمؤهل العلمي (بكالوريوس -

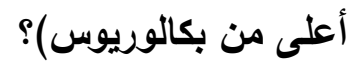
•) ما طبيعة العلاقة الارتباطية بين واقع إدارة المعرفة وتحقيق التميز المؤسسي بإدارة التعليم بالطائف؟

\section{أهداث الداساسة}

هدفت الاراسة إلى الكثف عن واقع إدارة المعرفة بإدارة التعليم بالطائف، وتحديد درجة تحقيق التميز المؤسسي بها، وكذلك الكثف عن دلالة الفروق الإحصائية في واقع تطبيق إدارة المعرفة ودرجة تحقيق التميز المؤسسي في إدارة تعليم الطائف والتي تُعزى إلى اختلاف عينة الدراسة في مواقعها القيادية (القيادات العليا- القيادات الوسطى - القيادات التفيذية)، والمؤهل العلمي (بكالوريوس- أعلى من بكالوريوس)، ومن ثمَ التعرف على طبيعة العلاقة الارتباطية بين واقع إدارة المعرفة وتحقيق التميز المؤسسي بإدارة التعليم بالطائف هئ

\section{أهمية الدداسبة} أولاً: الأهمية النظرية.

تستمد هذه الاراسة أهميتها النظرية من أهمية الموضوع الذي تناولته، فهي تتناول مبادرة من أهم المبادرات المطروحة في وقتنا الحاضر؛ لأن التغيرات المتسارعة التي حثث في العالم جعلت من إدارة المعرفة ضرورة ملحة لجميع مؤسسات المجتمع، وخاصة في

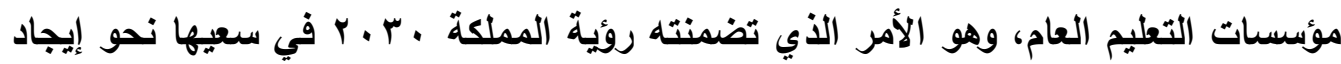


ثانياً: الأهمية التطبيقية.

تستمد هذه الدراسة أهيتها التطبيقية من سعيها نحو الكثف عن واقع تطبيق إدارة

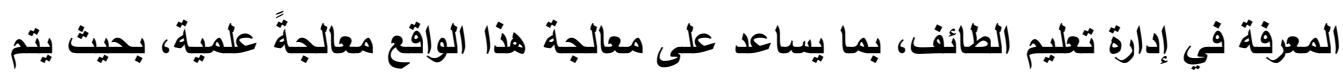

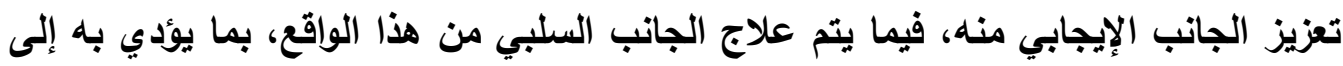
تحقيق التميز، كذلك فإنه من المأمول أن تسهم نتائج الدراسة في تزويد القائمين على إدارة التعليم بالطائف بالسبل التي تساعدهم في تطبيق إدارة المعرفة في مدارس الإدارة بجميع مراحلها، والتظلب على المعوقات التي تحول دون ذلكت.

\section{حدود الدراسة}

تمت الاراسة الحالية وفق الحدود الآتية:

1) الحدود الموضوعية: دراسة واقع تطبيق إدارة المعرفة، ودرجة تحقيق التميز المؤسسي.

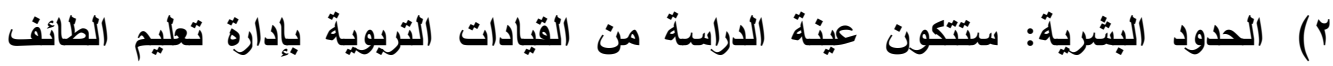

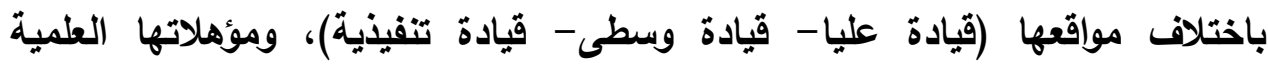

$$
\text { (بكالوريوس - أعلى من بكالوريوس). }
$$

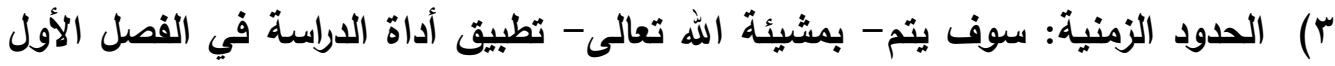

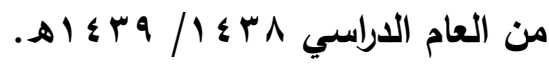

الحدود المكانية: سوف يتم تطبيق أداة الدراسة على القيادات التريوية بإدارة تعليم

الطائف.

\section{مفاهيم الدراسة:}

تناولت الدراسة الحالية مفهومين أساسين، وهو ما يمكن التأصيل لهما على النحو

التالي: - n - n

- Knowledge Administration إدارة المعرفة:

الإدارة هي النشاط الموجه نحو التعاون المثمر والتنسيق الفعَال بين الجهود البشرية

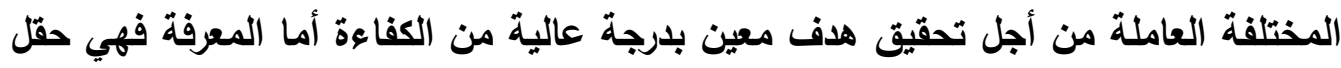

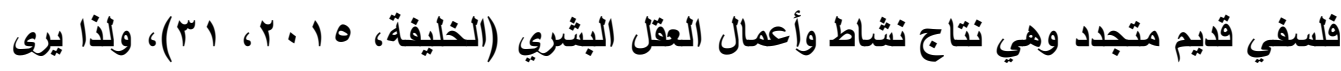

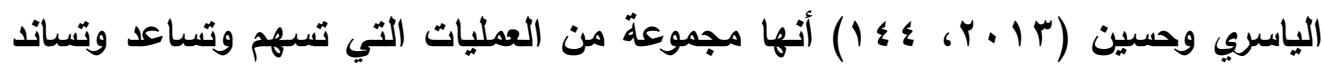

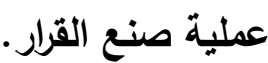


ولذا ينظر إلى مفهوم إدارة المعرفة على أنه الرصيد المعرفي القابل للاستخدام في أي مجال من المجالات، كما تشير إلى الاستراتيجيات والتراكيب التي تعظم من الموارد الفكرية

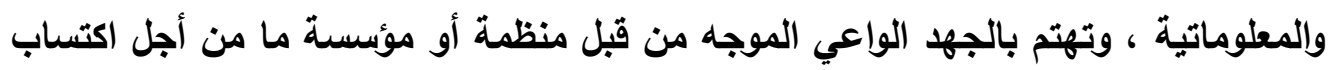

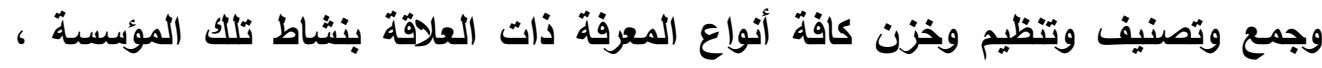
بالإضافة لكونها تعبر عن العمليات والأدوات والسلوكيات التي يشترك في صياغتها وأدائها المستفيدون من المنظمة، لاكتساب وخزن وتوزيع المعرفة لتنعكس على عمليات الأعمال

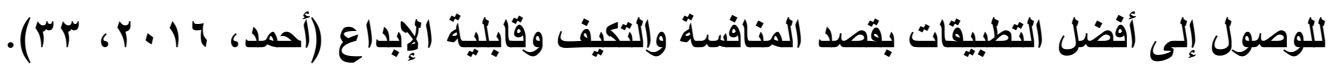
كذلك يُنظر لإدارة المعرفة على أنها "عملية ديناميكية مستمرة تتضمن مجموعة من

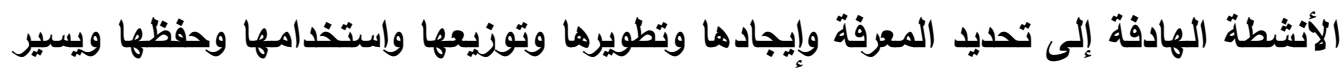

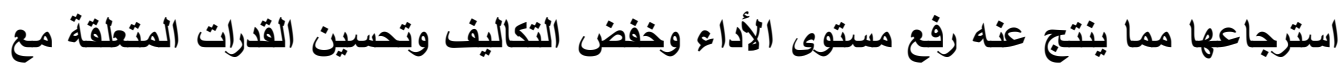

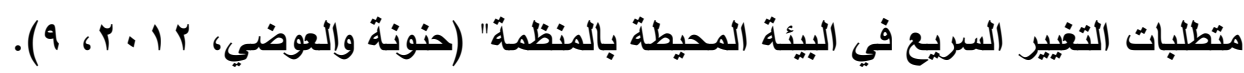

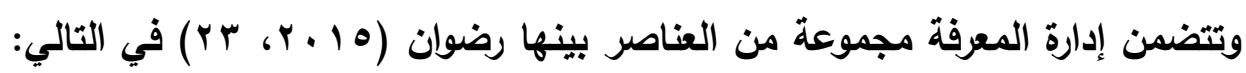
أنها إدارة نظامية صريحة وواضحة، وتحتوي على أنثطة وممارسات وسياسات ويرامج ترتبط

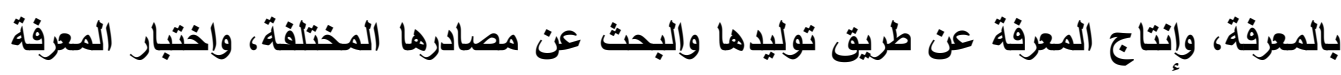
وتتقيحها وترشيحها وتبويبها وتصنيفها وتتظيمها، واستخدام مخرجات المعرفة برسم عمليات التعلم ويناء منظومة المعرفة والتخطيط الاستراتيجي.

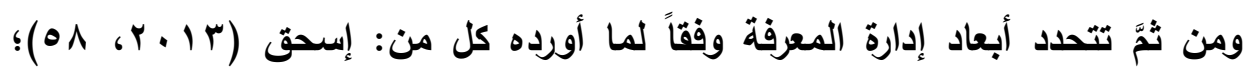

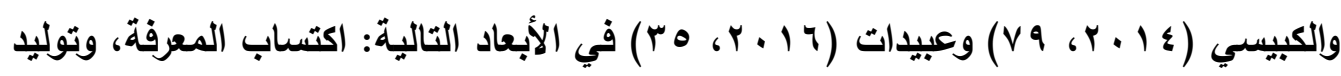
المعرفة، وخزن المعرفة، وتطبيق المعرفة، ومشاركة المعرفة.

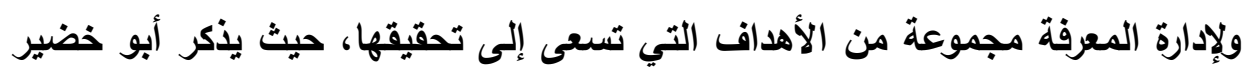

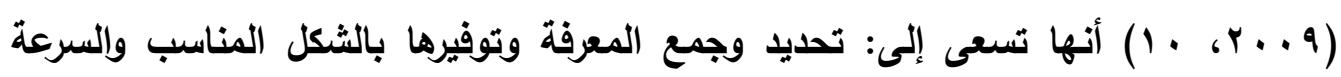

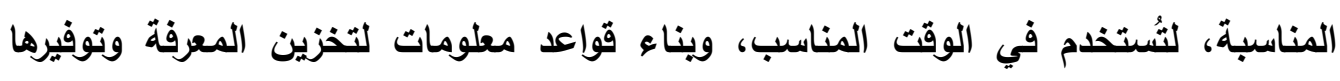
واسترجاعها عند الحاجة لها، وتسهيل عمليات تبادل ومشاركة المعرفة بين جميع العاملين في التظظيم، ونقل المعرفة الكامنة الضمنية في عقول ملاكها وتحويلها إلى معرفة ظاهرة.

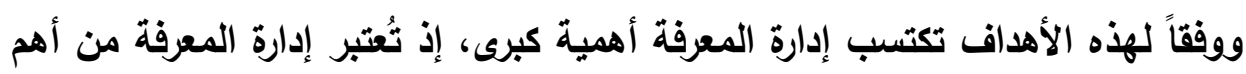
مدخلات التطوير والتغيير في عصرنا الحالي، حيث استطاعت إحداث نقلة نوعية من الترابط 
والانسجام ما بين إدارة المعرفة وأنشطة وفاعليات المؤسسات التريوية، بحيث يوجد قدر من التطابق بين المفهوم العملياتي للمعرفة، وآليات وأنشطة وفاعليات المؤسسة التربوية بصفتها

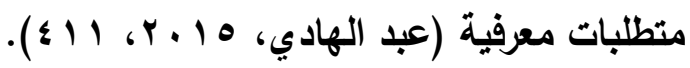
كما تؤدي إدارة المعرفة إلى تحقيق قيمة مضافة لمؤسسات التعليم، وتتمثل في: الوصول إلى أفكار ومشاركات إبداعية من مختلف المستويات الإدارية العاملة في المؤسسة، والسرعة في علاج المشاكل بتوفير جميع المعلومات المطلوية، وزيادة مستوى أداء العاملين

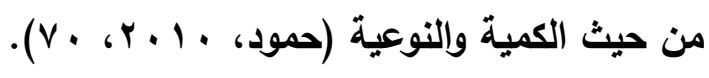

- التميز المؤسسي Organizational Excellence: الأداء المؤسسي للمنظمة ككل هو نتاج يعكس مدى استجابة المنظمة بفاعلية لظروف ومتغيرات البيئة الداخلية والخارجية، وكذلك لتوقعات الأطراف ذات العلاقة في هذه البيئة فهناك العديد من الأطراف التي تؤثر في تحديد روية ورسالة وأهداف المنظمة استراتيجية

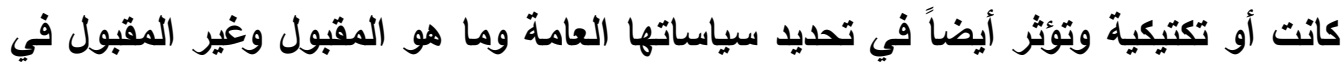

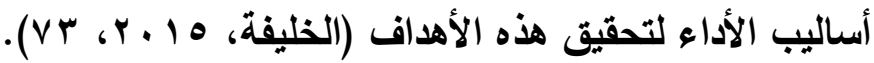

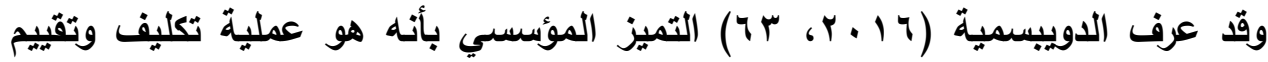
ذاتي لتحسين فاعلية المنظمة، وتحسين موقفها التنافسي ومرونة العمل فيها، وهو عملية

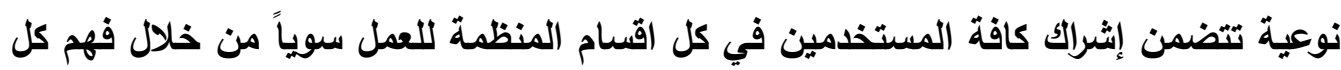

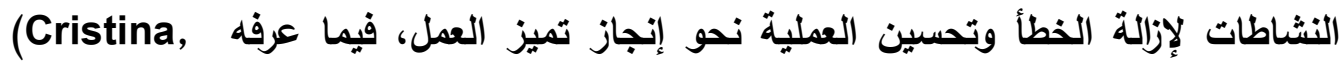
بele\& Colurcio, Maria, 2006, 471) والآليات التي يتم تطبيقها للتحسين المستمر في العمل لتحقيق الكفاعة والفاعلية والجودة في ماله الأداء، ولذا يعمل التميز والتطوير المؤسسي على تحقيق الأهداف التالية: تعزيز مشاركة العاملين في تطبيق معايير التميز العالمية، ونشر ثقافة التميز في المؤسسة، وتعظيم الاستفادة من الموارد المتاحة . ويشتمل التميز المؤسسي إلى مجموعة من العناصر التي يعد كل منها مجالاً لتحقيق التميز، وهي: التميز القيادي، والتميز الخدماتي، والتميز المعرفي، ومن أبرز خصائص التمئيل التميز المؤسسي: قبول الأعمال الصعبة: يعد من أهم مصادر التميز المؤسسي، حيث فرص النمو والتعلم السريع للمنظمات وتحسين العمليات ويدء العمل من الصفر، وتحمل المصاعب: 
توضح مستويات قدرة المنظمات، إذ إن ارتكاب الأخطاء وتحمل المنظمة للأزمات ومواجهتها يسهم في صقل قدرات المنظمة وتميزها، والخبرات البعيدة عن العمل: المنظمات المتميزة

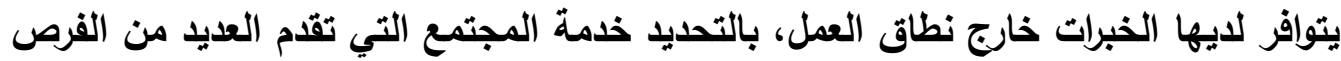

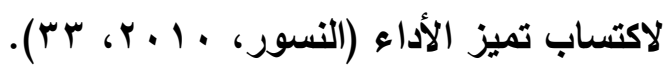

ويحتاج تحقيق التميز إلى جهود متواصلة في المؤسسة ووقت ليس بالقليل ويكلفة

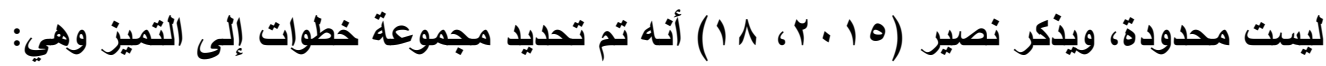
التحليل والتخطيط ووضع الأهداف وإصدار خطط العمل، وتتفيذ خطط العمل وذلك بالتنسيق مع برامج تربط فريق المؤسسة، والمتابعة والتقييم وتبادل الخبرات.

اللدراسات السابثة2:

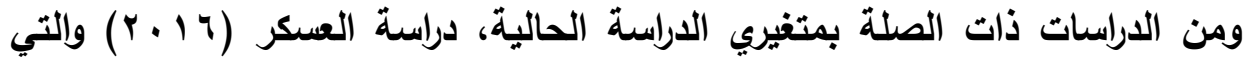

هدفت إلى الكثف عن تطوير أداء قائدات مدارس تطوير في منطقة الرياض على ضوء آليات إدارة المعرفة، وقد خلصت الدراسة إلى مجموعة من النتائج منها: أكد أفراد عينة الدراسة موافقتهم بشدة على دور الاجتماعات في تطوير أداء قائدات مدارس تطوير بمنطقة الرياض على ضوء آليات إدارة المعرفة. أما دراسة الشهري (10 + ب) فقد هدفت الدراسة إلى الكشف عن واقع تطبيق إدارة المعرفة في المدارس الثانوية بإدارة تعليم محايل من وجهة نظر مدرائها ووكلائها، ومعوقات تطبيق إدارة المعرفة في المدارس الثانوية، وكذلك منطلبات تطبيق إدارة المعرفة في المدارس الثانوية، وخلصت الدراسة إلى أن ممارسة عملية تطبيق عمليات إدارة المعرفة جاءت جميعها بارجة متوسطة، وأن معوقات تطبيق إدارة المعرفة (المعوقات التنظيمية والمعوقات البشرية

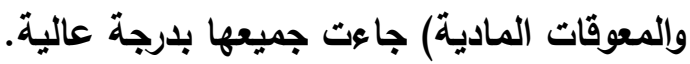

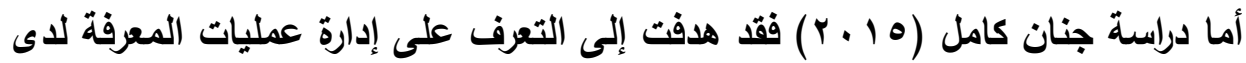
مديري مدارس المتميزين في بغداد من وجهة نظر المعاونين- المعاونات والمدرسينالمدرسات، وقد أظهرت النتائج أن مديري مدارس المتميزين لايهم إدارة عمليات المعرفة (توليد المعرفة، وتخزين المعرفة، وتبادل المعرفة، وتطبيق المعرفة) من وجهة نظر أفراد 
كما هدفت دراسة أبو حطب (10 ب ب) إلى الكشف عن درجة ممارسة مديري مدارس وكالة الغوث بمحافظات غزة للتخطيط الاستراتيجي المدرسي وعلاقتها بمستوى تطبيق ادارة المعرفة، وأظهرت النتائج أن مستوى إدارة المعرفة لاى مديري مدارس وكالة الغوث بمحافظات

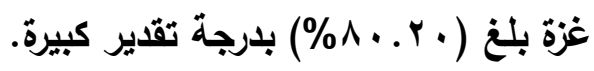
كذلك هدفت دراسة الحربي (ع ا ب r) إلى التعرف على واقع ممارسة المديرين لعمليات إدارة المعرفة في مدارس التعليم العام بينبع، وتوصلت الدراسة إلى عدد من النتائج من

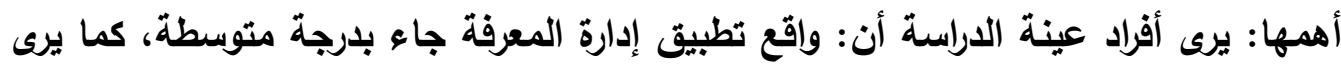
أن جميع عمليات إدارة المعرفة لاى مديري التعليم العام بينبع، جاعت بلرجة متوسطة.

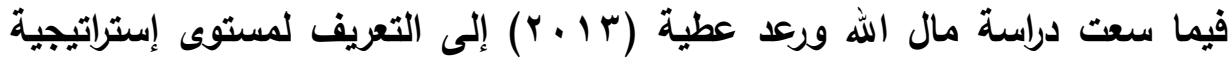
إدارة المعرفة ومستوى المهارات الإدارية لدى مديري ومديرات المدارس الإعدادية من وجهة نظر أعضاء الهيئة التدريسية وقد بينت النتائج امتلاك مديري ومديرات المدارس الإعدادية لاستراتيجية إدارة المعرفة بدرجة (كبيرة)، كما لا توجد فروق ذات دلالة إحصائية من وجهة

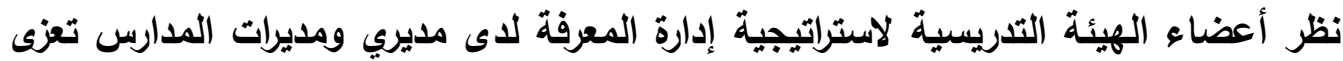

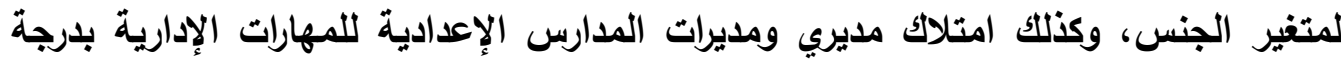
(كبيرة).

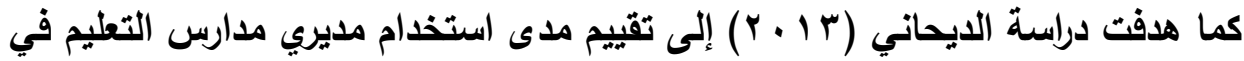
دولة الكويت لمهارات إدارة المعرفة وأساليب اتخاذ القرار، والعلاقة بينهما من وجهة نظر ماتري المديرين المساعدين، وأثارت النتائج إلى ارتفاع مستوى تطبيق مهارات إدارة المعرفة لدي مديري مدارس التعليم العام بدولة الكويت.

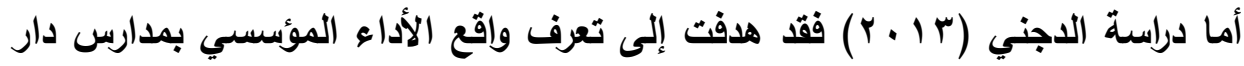
الأرقم بمحافظات غزة في ضوء النموذج الأوربي للتميز وسبل تطويره، واتبعت الدراسة المنهج الوصفي حيث تم تطوير استبانتين وتطبيقهما على ( V V^) عضواً (أكاديمي- إداري) وخلصت الدراسة إلى أن درجة تقدير العاملين بمدارس دار الأرقم للأداء المؤسسي لمدارسهم قد جاعت متوسطة، ولا يوجد فروق دالة إحصائياً لتقييم الأداء المؤسسي يعزى إلى الورئ الوظيفة، فيما وجدت فروق بين استجابات عينة الدراسة تعزى إلى متغير الخبرة. 
وتتميز الدراسة الحالية بكونها من الدراسات القليلة- في حدود علم الباحث- التي

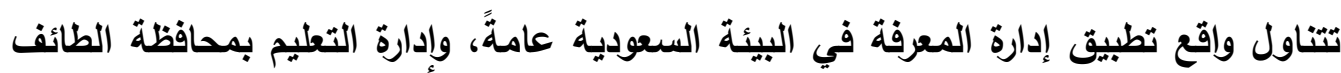

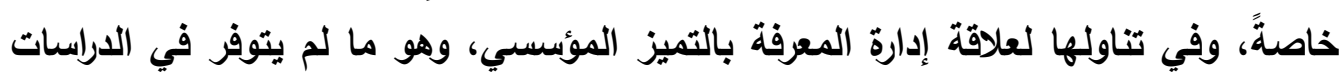
السابقة.

\section{منوجية الداراسة}

- منهج الدراسة:

اعتمدت الاراسة الحالية في تحقيقها لأهدافها على المنهج الوصفي؛ والذي يهدف إلى تصوير الوضع الراهن، وتحديد العلاقات التي قد توجد بين الظواهر المختلفة (أبوعلام،

$$
\begin{aligned}
& \text {. } r \wedge \leq 6 \text { ، }) \text {. } \\
& \text { - مجتمع الدراسة: }
\end{aligned}
$$

تكون جميع القيادات التريوية بإدارة تعليم الطائف، وذلك بمستوياتها الثثلاثة التالية:

\begin{tabular}{|c|c|c|c|}
\hline القياديادية مدرسئة التنفيذية & (مدير مكتب التعليم- القياد اتوسئ & ومساعدير التعليم القيادات العليا & مستوى القيادة \\
\hline Trq & r. & 01 & العدد \\
\hline \multicolumn{3}{|c|}{090} & إلمالي أفراد \\
\hline
\end{tabular}

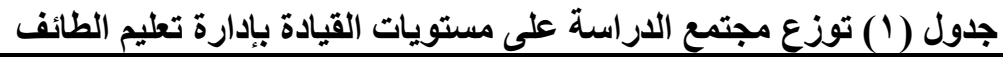

- عينة الاراسة: - مئمع

تم اختيار عينة الدراسة بالطريقة المسحية مع القيادات العليا، ويالطريقة الطبقية

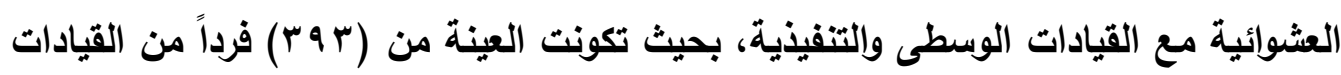
التريوية العليا والوسطة والتنفيذية. نظراً لطبيعة الدراسة من حيث أهدافها، ومنهجها، ومجتمعها، استخدمت الدراسة الاستبانة كأداة لجمع المعلومات والبيانات المتعقة بهذه الاراسة، ومر بناء الاستبانة بالخطوات العملية التالية: 
ا. تحديد الغرض العام للأداة وأهداف الاستبانة: والمتمثل في تحديد درجة تطبيق مضامين إدارة المعرفة في إدارة تعليم الطائف وعلاقته بالتميز المؤسسي، وذلك من وجهة نظر القيادات التريوية العاملة بها r. مراجعة الأدب النظري للاراسة والدراسات السابقة: خاصة الأدبيات التي هدفت إلى قياس

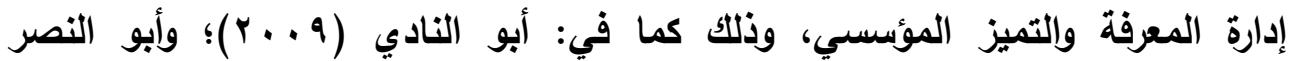
$\cdot(r \cdot 1 r)$ r. تحديد مجالات وأبعاد القياس لأداة الدراسة: والتي تحددت في: القسم الأول: بيانات المستجيب. القسم الثاني: يقيس جوانب تحقى إدارة المعرفة في مؤسسات التعليم والتي تتضمن أربعة أبعاد وهي (إنتاج وتوليا المعرفة- تخزين المعرفة- تثارك المعرفة- تطبيق المعرفة). القسم الثالث: التميز المؤسسي؛ حيث تم قياس هذا المتغير وفق معايير التميز التي وضعتها وزارة التعليم لجائزة التعليم المتميز، وتتحدد في (9) أبعاد (معاييز) وهي (القيادة الإدارية- - السياسات والاستراتيجيات- الموارد البشرية- الشراكة والموارد- - إدارة العمليات- الإدارة الإكترونية- التركيز على المستفيدين - التأثير على المجتمع - نتائج الأداء الرئيسة). ع ـ صياغة فقرات الأداة بصورتها الأولية: بعد تحديد مجالات الاستبانة، تم صياغة فقرات أداة

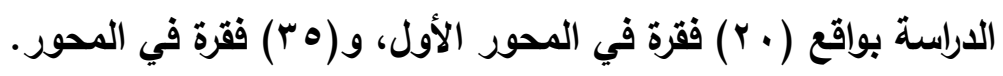
ه. تحديد تدريج الاستجابات للفقرات: حيث تم استخدام مقياس ليكرت (Likert) الخماسي

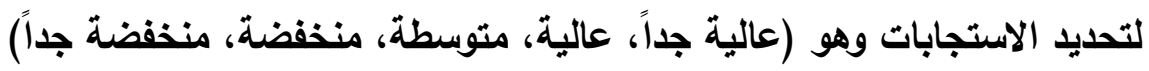
7. حساب الخصائص السيكومترية لأداة الاراسة: وقد تم ذلك على النحو التالي: حساب صدق أداة الدراسة. ( ) الصدق الظاهري (صدق المحكمين): تم عرض الاستبانة في صورتها الأولية على مجموعة من المحكمين من أعضاء هيئة

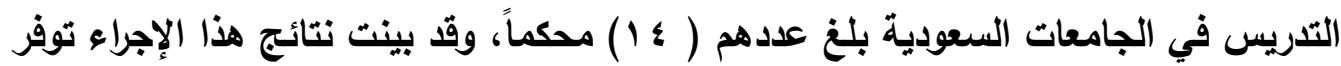
مؤثثر الصدق الظاهري للاستبانة.

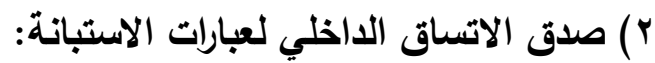


تم تطبيق الاستبانة على عينة استطلاعية من خارج العينة الأصلية قوامها ـ ب فرداً، بعدها قام الباحث بحساب صدق البناء الداخلي للاستبانة، وذلك على النحو التالي:

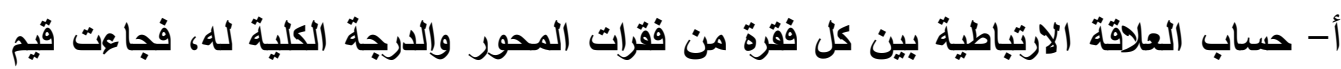

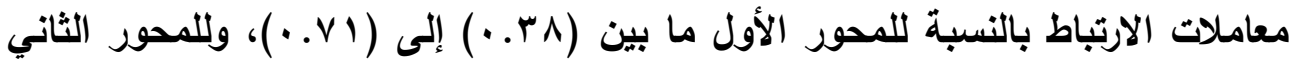

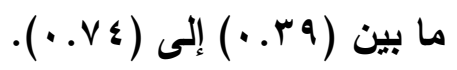

ب- حساب العلاقة الارتباطية بين كل فقرات من فقرات المحور الأول للاستبانة، والدرجة الكلية للبعد الذي تنتمي له، فجاءت قيم معاملات الارتباط بالنسبة للمحور الأول ما بين

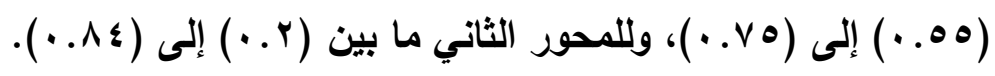

ج- حساب العلاقة الارتباطية بين كل من الدرجة الكلية لكل بعد من أبعاد المحور الأول في الاستبانة ويعضها البعض من جهة، ويينها وبين الارجة الكلية للمحور من جهة أخرى،

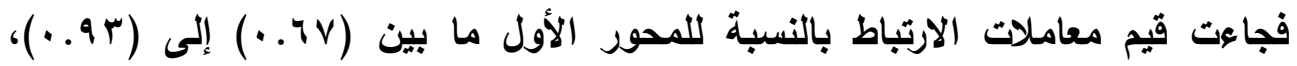

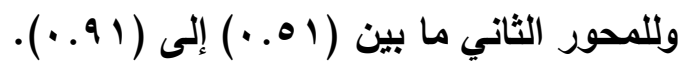

حساب ثبات أداة الدراسة:

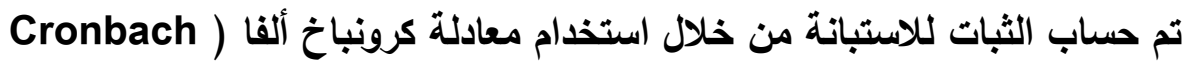

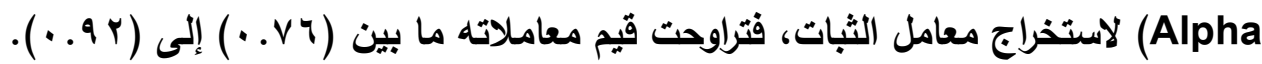
ولهدف المكم على استجابات أفراد عينة الدراسة على أبعاد المقياسين، تم حساب الوزن النسبي لبدائل الاستجابة على فقراتهما على النحو الآتي:

$$
\text { - طول الفئة= المدى/ لعدد الفئات. }
$$

- المدى= الفرق بين أكبر وأصغر بديل (درجة بديل الاستجابة) / عدد بدائل الاستجابة.

$$
\text { - المدى = (1-0) }
$$

ويالتالي يكون مقياس الحكم على درجة التوفر على النحو الآتي:

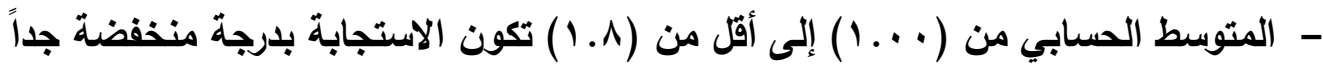

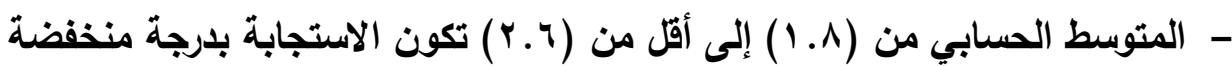

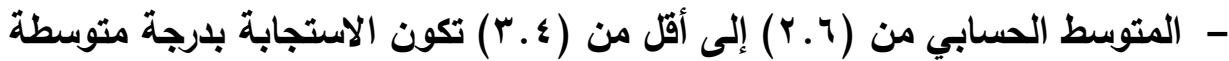

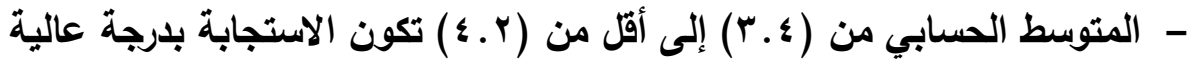

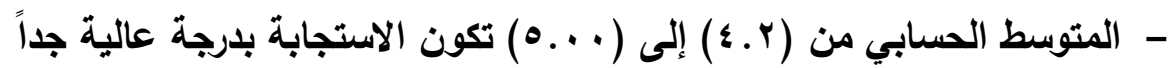




\section{تقائج الدراسة ومنا تشمتها وتفسيرها:}

النتائج المتعلقة بالسؤال الأول ومناقشتها وتفسيرها: والذي ينص على "ما واقع تطبيق إدارة المعرفة بإدارة التعليم بالطائف من وجهة نظر

القيادات التربوية العاملة بها"؟

وللإجابة عن هذا السؤال تم تحليل استجابات عينة الدراسة من القيادات التربوية العاملة بإدارة التعليم على المحور الأول الاستبانة، وما يتضمنه من أبعاد لواقع تطبيق إدارة

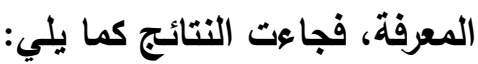

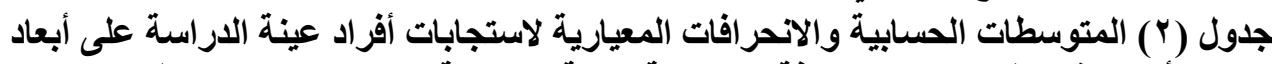

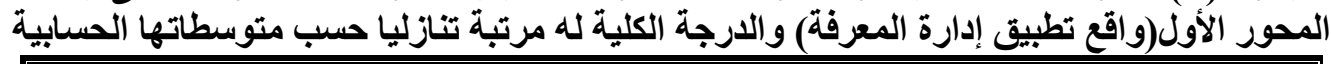

\begin{tabular}{|c|c|c|c|c|c|}
\hline الرتبة & التطبيق & الانحراف & الحستبي & البعد & رقا الاستبانة في \\
\hline 1 & متوسطة & 0.93 & 2.87 & تشارك المعرفة & $r$ \\
\hline$r$ & متوسطة & 0.9 & 2.77 & إنتاج وتوليد المعرفة & 1 \\
\hline$r$ & متوسطة & 0.85 & 2.62 & تطبيق المعرفة & $\varepsilon$ \\
\hline$\varepsilon$ & منغفضة & 0.95 & 2.47 & تخزين المعرفة & $r$ \\
\hline \multicolumn{2}{|c|}{ متوسطة } & 0.91 & 2.68 & \multicolumn{2}{|c|}{ الدرجة الكلية لواقع تطبيق إدارة } \\
\hline
\end{tabular}

تبين النتائج في الجدول (Y) أن الدرجة الكلية لتقدير أفراد عينة الدراسة لواقع تطبيق

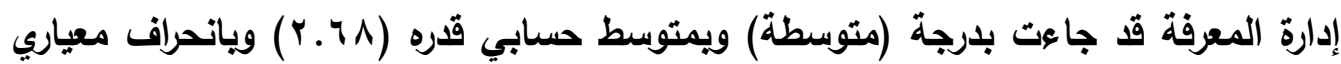
.$(\cdot .91)$

ويعزو الباحث الدرجة المتوسطة لواقع تطبيق إدارة المعرفة بإدارة التعليم بمحافظة الطائف إلى مجموعتين من العوامل: أولها؛ إدراك القيادات التريوية أن تطبيق إدارة المعرفة هو من المجالات الحديثة في مجال التربية عموماً، وفي مجال التطوير- الذي تنشده

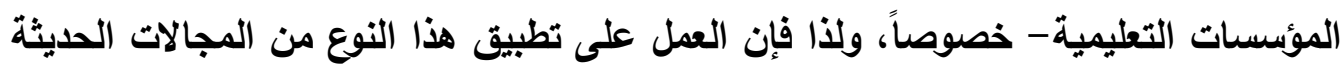
في إدارة التعليم ما زال في بداياته، ولذا فإنه من الطبيعي أن إدارة التعليم ما زالت بصدد العمل على توفير المتطلبات الخاصة بنشر وتطبيق هذا المفهوم في المدارس التابعة لها في شتى القطاعات والمراحل التعليمية من الابتدائية إلى الثانوية. كذلك قد تُعزى النتيجة الحالية إلى الظروف الخاصة بتطبيق هذا المجال في البيئة التريوية بوجه عامة، وهي ظروف تتعلق بعملية التحول المعرفي في المجتمع السعودي، من 


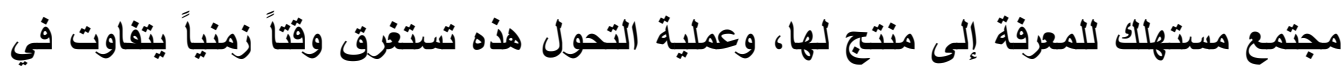

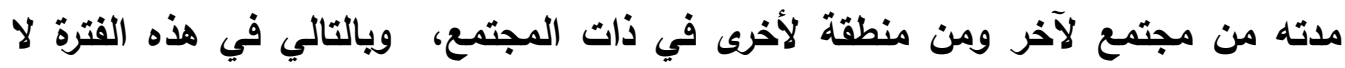

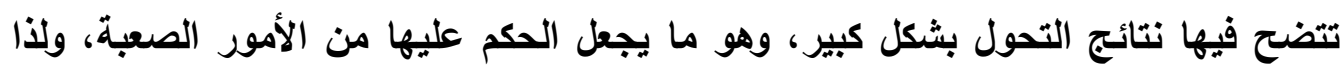
جاء إدراك عينة الاراسة لواقع تطبيق إدارة المعرفة متوسطاً .

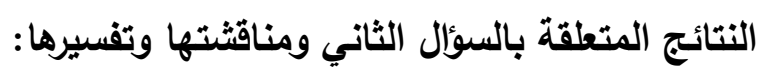

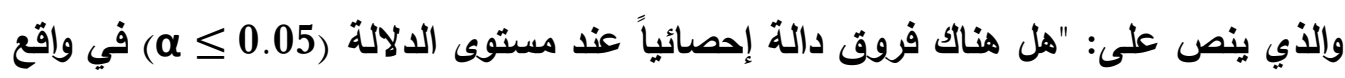

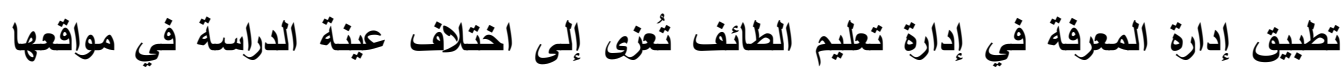

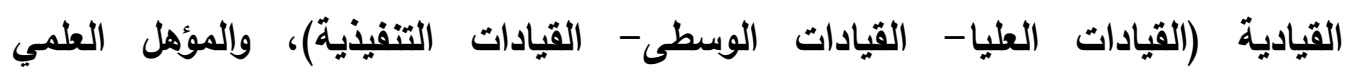

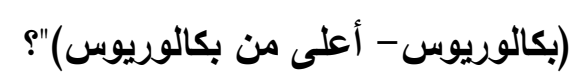

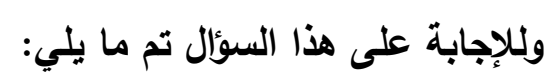

(1) حساب دلالة الفروق في واقع تطبيق المعرفة حسب متفير (الموقع القيادي):

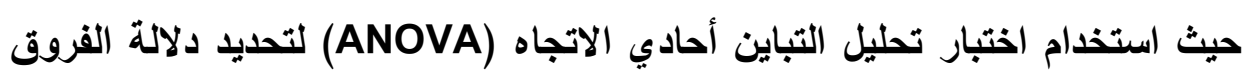

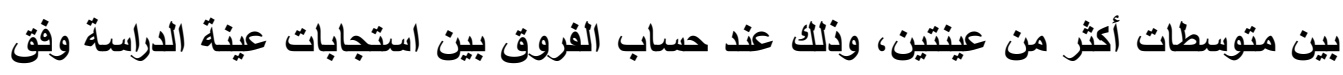

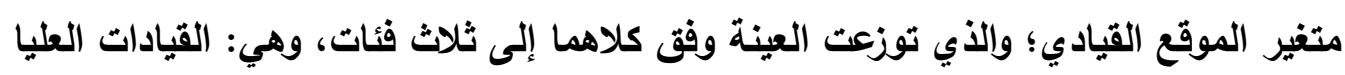

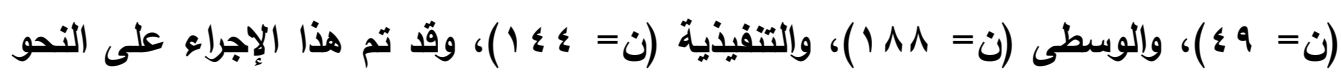
التالي: (ن) (ب) جدول (") نتايج تحليل أحادي الاتجاه للفروق بين متوسطات استجابات عينة الاراسة على المحور الأول للاستباتة طبقاً لمتغير الموقع القيادي

\begin{tabular}{|c|c|c|c|c|c|c|}
\hline الإحصائية & قفيمة & متوسطات & الدرجية & مجموع مربعات & مصدر التباين & حاور \\
\hline \multirow{3}{*}{0.01} & \multirow{3}{*}{12.72} & 170.29 & 2 & 340.57 & بين المجموعات & \multirow{3}{*}{ إلنتاج وتوليد } \\
\hline & & 1339 & 390 & 5220.27 & داخل المجموعات & \\
\hline & & & 392 & 5560.84 & المجموع & \\
\hline \multirow{3}{*}{0.05} & \multirow{3}{*}{3.90} & 77.54 & 2 & 155.07 & بين المجموعات & \multirow{3}{*}{ خززين المعرفة لم } \\
\hline & & 19.89 & 390 & 7757.58 & داخل المجموعات & \\
\hline & & & 392 & 7912.66 & المجموع & \\
\hline \multirow{3}{*}{0.01} & \multirow{3}{*}{12.95} & 206.36 & 2 & 412.72 & بين المجموعات & \multirow{3}{*}{ تثنارك المعرفة } \\
\hline & & 15.93 & 390 & 6213.91 & داخل المجموعات & \\
\hline & & & 392 & 6626.63 & المجموع & \\
\hline 0.01 & 12.43 & 159.30 & 2 & 318.60 & بين المجموعات & تطبيق المعرفة \\
\hline
\end{tabular}


واقع تطبيق مضامين إدارة المعرفة في إدارة تعليم الطائف وعلاقته بالتميز المؤسسي من وجهة نظر القيادات العاملة بها.

\begin{tabular}{|c|c|c|c|c|c|c|}
\hline الإحصائية & قة قةمة & متوسط المربعات & |الررية & مجموع مربعات & مصدر التباين & المحاور \\
\hline & & 12.82 & 390 & 4998.46 & داخل المجموعات & \\
\hline & & & 392 & 5317.06 & المجموع & \\
\hline \multirow{3}{*}{0.01} & \multirow{3}{*}{10.66} & 2057.84 & 2 & 4115.68 & بين المجموعات & \multirow{3}{*}{ المحور الأولة الكلية } \\
\hline & & 193.09 & 390 & 75304.19 & داخل المجموعات & \\
\hline & & & 392 & 79419.87 & المجموع & \\
\hline
\end{tabular}

تظهر نتائج الجدول (r) وجود فروق ذات دلالة إحصائية في استجابات أفراد عينة الدراسة على المحور الأول للاستبانة تُعزى لمتغير الموقع القيادي، وذلك في كل من جميع أبعاد المحور الأول والدرجة الكلية له. ومع دلالة قيمة (ف) ذات دلالة إحصائية عند مستوى (a) اختبار شيفيه (Scheffe) للمقارنات البعدية المتعددة، وذلك لتحديد اتجاه الفروق في هذا

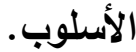
جدول (؛ ) نتائج اختبار المقارنات البعدية المتعددة للفروق الدالة لاستجابات العينة على المحور الأول للاستبانة (الأبعاد والدرجة الكلية) طبقاً لمتغير الموقع القيادي لانيات

\begin{tabular}{|c|c|c|c|c|c|}
\hline (دال لصالح) & الالالة & متوسطين & المجموعة (ب) & المجموعة (أ) & البعد \\
\hline القيادات & $\because \cdot 1$ & $* Y . V \leq$ & الوسيادات & \multirow{2}{*}{ القيادات العليا } & \multirow{2}{*}{ إنتاج وتوليد } \\
\hline القيادات & $\because \cdot 1$ & $* Y . \wedge q$ & التنيذية التياد & & \\
\hline القيادات & $\because .0$ & $* 1.0 \leq$ & الوسيادات & القيادات العليا & المعزينة \\
\hline القيادات & $\because \cdot 1$ & $* r . Y$. & الوسيطى القياد & \multirow{2}{*}{ القيادات العليا } & \multirow{2}{*}{ تشعارك } \\
\hline القيادات & $\because+1$ & $* Y .90$ & التنقيذادات & & \\
\hline القيادات & $\because \cdot 1$ & $* Y . V V$ & الوسيادات & \multirow{2}{*}{ القيادات العليا } & \multirow{2}{*}{ المعرفيقة } \\
\hline القيادات & $\because \cdot 1$ & *Y.TV & التقيذادات & & \\
\hline القيادات القليات & $\because \cdot 1$ & $* 1 \cdot . r \leq$ & الوسيادات & \multirow{2}{*}{ القيادات العليا } & \multirow{2}{*}{ للمحور الأولة الكلية } \\
\hline القيادات & $\because \cdot 1$ & $* \wedge .9$. & التنقيذادات & & \\
\hline
\end{tabular}


يظهر من الجدول (ع) أن اتجاه دلالة الفروق يكون لصالح القيادات العليا، أي عينة الدراسة من القيادات العليا للتعليم ترى بصورة أوضح من غيرها من القيادات وجود تطبيق

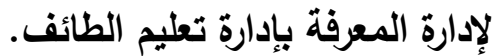

ويعزو الباحث النتيجة الحالية في دلالتها على وجود فروق في استجابات عينة الدراسة في واقع تطبيق إدارة المعرفة حسب الموقع القيادي لعينة الدراسة، أن القيادات العليا هي المنوط بها بالارجة الأولى تحقيق هذا الأمر، وهي ترى أنها بذلت الجهود المناسبة في

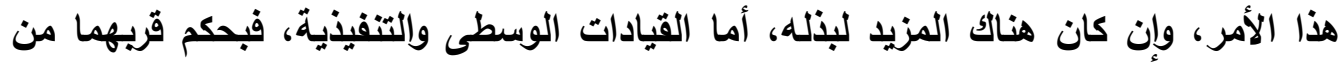
الواقع، فقد أدركا واقع تطبيق إدارة المعرفة بشكل مغاير عن إدراك القيادات العليا له، وذلك في كل من الأبعاد والدرجة الكلية للمحور الأول للاستبانة، فجاءت استجابات هاتين الفئتين

في تقييمهما لواقع تطبيق إدارة المعرفة بدرجة أقل من تقييم القيادات العليا.

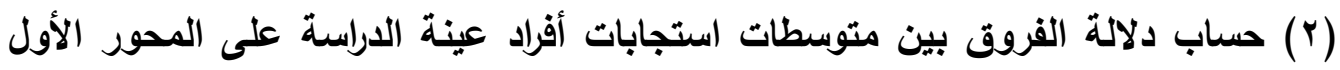
من الاستبانة طبقاً لمتغير (المؤهل العلمي):

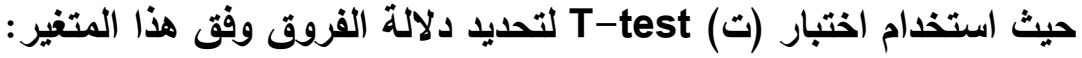
جدول (•) نتائج اختبار (ت) لالالة الفروق بين استجابات عينة الدراسة على المحور الأول للاستبانة وفقاً لمتغير المؤهل العلمي المينة

\begin{tabular}{|c|c|c|c|c|c|c|c|c|}
\hline الإحصائية & قتثة & لدرجة & الانحرا & الحسا & العدد & المجموعات & الأسلوب & p \\
\hline \multirow[b]{2}{*}{$\because \cdot 1$} & \multirow[b]{2}{*}{ 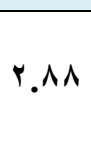 } & \multirow[b]{2}{*}{ rql } & 3.70 & 13.59 & MYY & بكالوريوس & \multirow[b]{2}{*}{ إلتاج وتوليد } & \multirow[b]{2}{*}{1} \\
\hline & & & 3.85 & 15.00 & $v_{1}$ & ألبكالوريوس من & & \\
\hline \multirow[b]{2}{*}{$\because \cdot 1$} & \multirow[b]{2}{*}{ r.r. } & \multirow[b]{2}{*}{ rql } & 4.52 & 11.98 & MYY & بكالوريوس & \multirow[b]{2}{*}{ المعزينة } & \multirow[b]{2}{*}{ r } \\
\hline & & & 4.01 & 13.92 & VI & أبكالعلى من & & \\
\hline \multirow[b]{2}{*}{$\because 0$} & \multirow[b]{2}{*}{ r.rq } & \multirow[b]{2}{*}{ rql } & 4.17 & 14.11 & MYY & بكالوريوس & \multirow[b]{2}{*}{ تثماركة } & \multirow[b]{2}{*}{$r$} \\
\hline & & & 3.69 & 15.39 & vi & أبكالولى من & & \\
\hline \multirow[b]{2}{*}{$\because \bullet$} & \multirow[b]{2}{*}{ ד.r. } & \multirow[b]{2}{*}{ rql } & 3.68 & 12.88 & MYY & بكالوريوس & \multirow[b]{2}{*}{ تطبيقي } & \multirow[b]{2}{*}{$\varepsilon$} \\
\hline & & & 3.59 & 14.01 & vi & أبكالولى من & & \\
\hline \multirow[b]{2}{*}{$\because+1$} & \multirow[b]{2}{*}{ r.M } & \multirow[b]{2}{*}{ rql } & 14.37 & 52.57 & MrY & بكالوريوس & \multirow{2}{*}{\multicolumn{2}{|c|}{ للادحور الأولية }} \\
\hline & & & 12.64 & 58.32 & $v_{1}$ & ألبكالوريوس من & & \\
\hline
\end{tabular}


يتبين من الجدول (ه) السابق ما يلي: وجود فروق ذات دلالة إحصائية عند مستوى

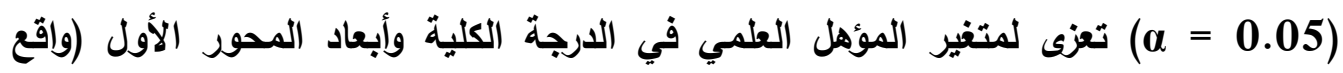
تطبيق إدارة المعرفة) لصالح فئة الحاصلين على مؤهل أعلى من بكالوريوس.

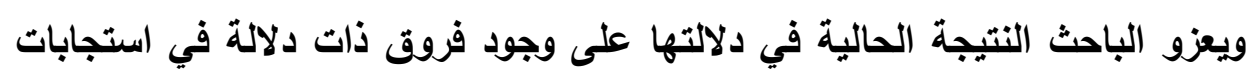

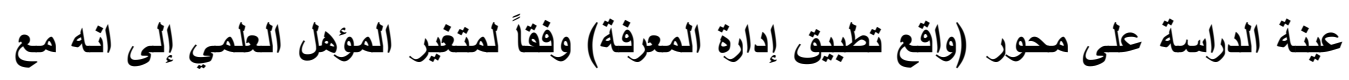

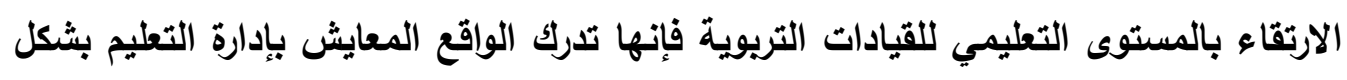
مغاير، حيث يبدو تقييها أكثر موضوعية ومعرفة بما ينبغي أن يكون تجاه تطبيق إدارة المعرفة، وترتب على ذلك أن تباعدت استجابات عينة الدراسة على المحور الأول للاستبانة

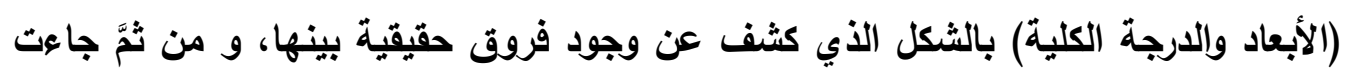
قيمة (ت) للفروق بين مجموعتي الدراسة طبقاً للمؤهل العلمي دالة إحصائياً. النتائج المتعلقة بالسؤال الثالث ومناقشتها وتفسيرها : والذي ينص على "ما درجة تحقيق التميز المؤسسي بإدارة التعليم بالطائف من وجهة نظر القيادات التريوية العاملة بها"؟ وللإجابة عن هذا السؤال تم تحليل استجابات عينة الدراسة من القيادات التريوية

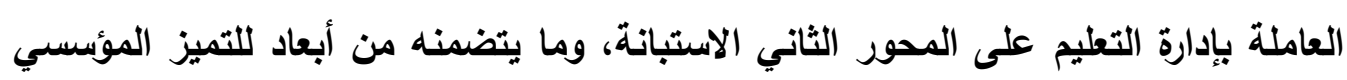

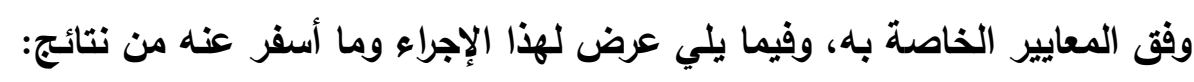

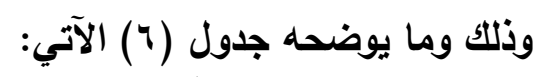

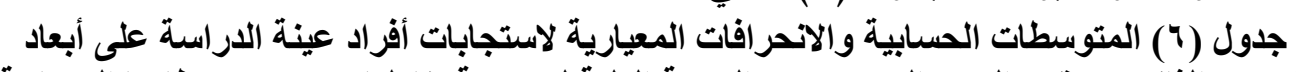

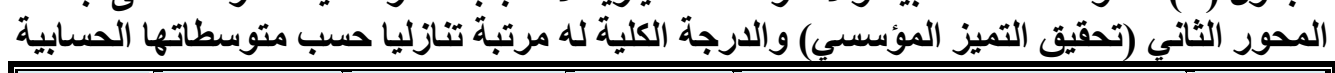

\begin{tabular}{|c|c|c|c|c|c|}
\hline الرتبة & التحققّ & المعياري & الحسابي & البعد & رقم البعد \\
\hline 1 & عالية & 0.86 & 3.49 & الإدارة الإكترونية & 7 \\
\hline$r$ & متوسطة & 0.80 & 3.19 & السياسات والاستر اتيجيات & r \\
\hline$r$ & متوسطة & 0.82 & 3.09 & نتائج الأداء الرئيسة & 9 \\
\hline$\varepsilon$ & متوسطة & 0.82 & $\mathbf{3 . 0 3}$ & القيادة الإدارية & 1 \\
\hline - & متوسطة & 0.84 & 2.87 & الموارد البشرية & $\mu$ \\
\hline 7 & متوسطة & 0.80 & 2.85 & الثر اكة والموارد & $\varepsilon$ \\
\hline $\mathrm{v}$ & متوسطة & 0.78 & 2.80 & إدارة العمليات & 0 \\
\hline$\Lambda$ & متوسطة & 0.80 & 2.79 & التأثير على المجتمع & $\Lambda$ \\
\hline 9 & متوسطة & 0.80 & 2.77 & التركيز على المستفيدين & $\mathrm{v}$ \\
\hline \multicolumn{2}{|c|}{ متوسطة } & 0.81 & 2.97 & \multicolumn{2}{|c|}{ الارجة الكلية للتميز المؤسسى } \\
\hline
\end{tabular}


تبين النتائج في الجدول (†) أن الدرجة الكلية لتقدير أفراد عينة الدراسة- من القيادات

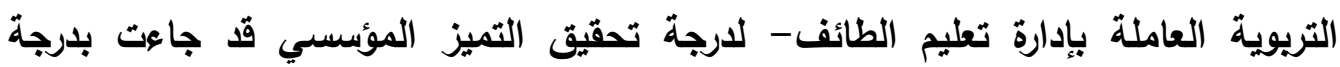

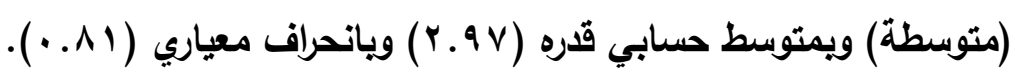

ويعزو الباحث الارجة المتوسطة لتحقيق التميز المؤسسي بإدارة تعليم الطائف من وجهة نظر القيادات التربوية العاملة بها إلى سعي إدارة التعليم بالطائف نحو تطبيق معايير جائزة التميز التي تقرها وزارة التعليم- والتي تم بناء فقرات هذا المحور وفقاً لها- وذلك وفتى بهات الاليل التفسيري لها، كذلك فإن هذا المستوى المتوسط إنما يعطي دلالة على امتلاك إدارة التعليم بالطائف لمستوى مناسب من الأداء المؤسسي الذي يمكن استغلاله لتحقيق التميز مع بذل المزيد من الجها، علماً بأن هذه هي السنة الثامنة في تطبيق معايير جائزة التميز للتعليم على مستوى إدارات التعليم بالمملكة العربية السعودية. كذلك يمكن تفسير هذا المستوى المتوسط من التميز المؤسسي إلى أن القيادات التريوية بإدارة تعليم الطائف في استجاباتها على فقرات هذا المحور أرادت توصيف الوضع كما هو بدون تحيز، وهو ما يشير إلى رغبة عينة الدراسة إلى تحقيق مستويات أفضل من التميز المؤسسي، والطموح لمستويات أعلى عبر امتلاك أدوات هذا التميز بدعًا من معيار القيادة التريوية إلى تقديم نتائج مخرجات المنظومة المتكاملة لأعمالها وأنشطتها المختلفة في ضوء تفاعلها مع مكوناتها ومحيطها وفقاً لمعيار (نتائج الأداء الرئيسة). النتائج المتعلقة بالسؤال الثاني ومناقشتها وتفسيرها: والذي ينص على: " هل هناك فروق دالة إحصائياً عند مستوى الدلاية (0.05) في درجة تحقيق التميز المؤسسي بإدارة تعليم الطائف تُعزى إلى اختلاف عينة الدراسة في مواقعها القيادية (القيادات العليا- القيادات الوسطى - القيادات التنفيذية)، والمؤهل العلمي

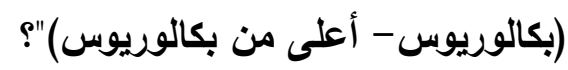

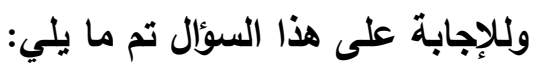
(r) حساب دلالة الفروق في درجة تحقيق التميز المؤسسي حسب متغير (الموقع القيادي):

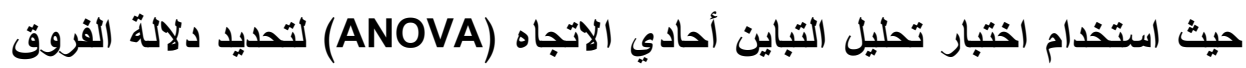
وفق متغير الموقع القيادي.

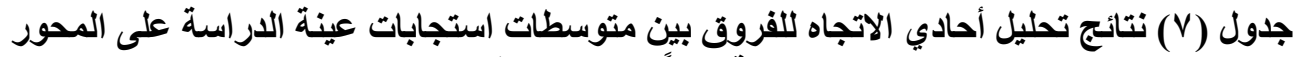
الثاني للاستبانة طبقاً لمتغير الموقع القيادي 
واقع تطبيق مضامين إدارة المعرفة في إدارة تعليم الطائف وعلاقته بالتميز المؤسسي من وجهة نظر القيادات العاملة بها.

\begin{tabular}{|c|c|c|c|c|c|c|}
\hline الإحصائية & قيمة & المربعات & الدرجية & مجموع مربعات & مصدر التباين & المحاور \\
\hline \multirow{3}{*}{0.01} & \multirow{3}{*}{19.20} & 139.261 & 2 & 278.52 & بين المجموعات & \multirow{3}{*}{ القيادة الإدارية } \\
\hline & & \multirow{2}{*}{7.255} & 390 & 2829.41 & داخل المجموعات & \\
\hline & & & 392 & 3107.93 & المجموع & \\
\hline \multirow{3}{*}{0.01} & \multirow{3}{*}{26.35} & $\mathbf{1 9 1 . 8 5 2}$ & 2 & 383.71 & بين المجموعات & \multirow{3}{*}{ والاستراتيجيات } \\
\hline & & 7.28 & 390 & 2839.14 & داخل المجموعات & \\
\hline & & & 392 & 3222.85 & المجموع & \\
\hline \multirow{3}{*}{0.01} & \multirow{3}{*}{17.60} & $\mathbf{1 2 7 . 3 3 4}$ & 2 & 254.67 & بين المجموعات & \multirow{3}{*}{ الموارد البشرية } \\
\hline & & 7.235 & 390 & 2821.57 & داخل المجموعات & \\
\hline & & & 392 & 3076.23 & المجموع & \\
\hline \multirow{3}{*}{0.01} & \multirow{3}{*}{9.98} & 79.814 & 2 & 159.63 & بين المجموعات & \multirow{3}{*}{ والموارد } \\
\hline & & 7.996 & 390 & 3118.29 & داخل المجموعات & \\
\hline & & & 392 & 3277.91 & المجموع & \\
\hline \multirow{3}{*}{0.01} & \multirow{3}{*}{12.09} & 128.36 & 2 & 256.72 & بين المجموعات & \multirow{3}{*}{ | إدارة العمليات } \\
\hline & & 10.613 & 390 & 4139.24 & داخل المجموعات & \\
\hline & & & 392 & 4395.96 & المجموع & \\
\hline \multirow{3}{*}{0.01} & \multirow{3}{*}{36.43} & 308.365 & 2 & 616.73 & بين المجموعات & \multirow{3}{*}{ الإكتترونية } \\
\hline & & 8.465 & 390 & 3301.35 & داخل المجموعات & \\
\hline & & & 392 & 3918.08 & المجموع & \\
\hline \multirow{3}{*}{0.01} & \multirow{3}{*}{5.44} & 25.387 & 2 & $\mathbf{5 0 . 7 7}$ & بين المجموعات & \multirow{3}{*}{ المستفيدين على } \\
\hline & & 4.669 & 390 & 1820.99 & داخل المجموعات & \\
\hline & & & 392 & 1871.76 & المجموع & \\
\hline \multirow{3}{*}{0.05} & \multirow{3}{*}{4.05} & 31.655 & 2 & 63.31 & بين المجموعات & \multirow{3}{*}{ التأثير على } \\
\hline & & 7.809 & 390 & 3045.53 & داخل المجموعات & \\
\hline & & & 392 & 3108.84 & المجموع & \\
\hline \multirow{3}{*}{0.01} & \multirow{3}{*}{15.92} & 212.129 & 2 & 424.26 & بين المجموعات & \multirow{3}{*}{ نتائج الأداء } \\
\hline & & 13.327 & 390 & 5197.60 & داخل المجموعات & \\
\hline & & & 392 & 5621.85 & المجموع & \\
\hline \multirow{3}{*}{0.01} & \multirow{3}{*}{22.05} & 9460 & 2 & 18920.00 & بين المجموعات & \\
\hline & & 429.014 & 390 & 167315.65 & داخل المجموعات & الدرجه الحية \\
\hline & & & 392 & 186235.65 & المجموع & \\
\hline
\end{tabular}

تظهر نتائج الجدول (V) وجود فروق ذات دلالة إحصائية في استجابات أفراد عينة

الدراسة على المحور الأول للاستبانة تُعزى لمتغير الموقع القيادي، وذلك في كل من جميع أبعاد المحور الثاني واللارجة الكلية له. 


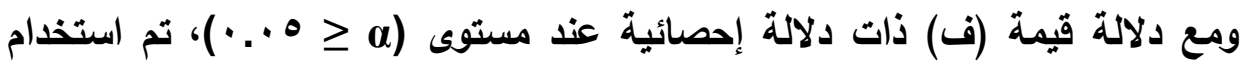
اختبار شيفيه (Scheffe) للمقارنات البعدية المتعددة، ولذلك لتحديد اتجاه الفروق في هذا الأسلوب، والجدول (V) يبين نتائج هذا الإجراء.

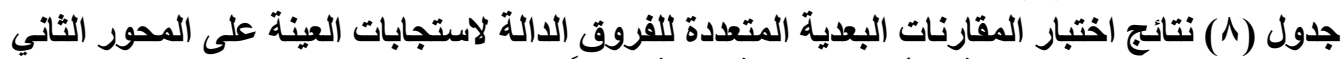

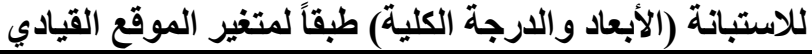

\begin{tabular}{|c|c|c|c|c|c|}
\hline (دال لصالح) & مستوي & متوسطين & المجموعة (ب) & المجموعة & البعد \\
\hline القيادات العليا & .1 & *Y.rq & القيادات الوسطى & \multirow{2}{*}{ القيادات } & \multirow{2}{*}{ القيادة الإدارية } \\
\hline القيادات العليا & $\because \cdot 1$ & *Y. & القيادات التنفيذية & & \\
\hline القيادات العليا & $\because \cdot 1$ & $* Y . \leqslant 0$ & القيادات الوسطى & \multirow{2}{*}{ القيادات العليا } & \multirow{2}{*}{ والاستراتيجيات } \\
\hline &.$\cdot 1$ & $* 4.19$ & القيادات التنفيذية & & \\
\hline القيادات العليا & $\because \cdot 1$ & *Y.rr & القيادات الوسطى & \multirow{2}{*}{ القيادات } & \multirow{2}{*}{ البشرية المواد } \\
\hline القيادات العليا &.$\cdot 1$ & *Y.Or & القيادات التنفيذية & & \\
\hline القيادات العليا & $\because \cdot 1$ & $* r_{.} \ldots$ & القيادات الوسطى & \multirow{2}{*}{ القيادات } & \multirow[b]{3}{*}{ والموارد } \\
\hline القيادات العليا &. .0 & $* 1.11$ & القيادات التنفيذية & & \\
\hline القيادات العليا & $\because 0$ & $* 1 . Y \Lambda$ & القيادات الو & القيادات & \\
\hline القيادات العليا & $\cdot$ & 7 & القيادات الوسطى & \multirow{2}{*}{ القيادات العليا } & \multirow{2}{*}{ إدارة العمليات } \\
\hline القيادات العليا & $\because \cdot 1$ & $* Y .0 Y$ & القيادات التنفيذية & & \\
\hline القيادات العليا & $\because \cdot 1$ & $* Y . \wedge V$ & القيادات الوسطى & \multirow{2}{*}{ القيادات العليا } & \multirow{2}{*}{ الإلكثرونية } \\
\hline القيادات العليا & $\because \cdot 1$ & $* \varepsilon .+r$ & القيادات التنفيذية & & \\
\hline القيادات العليا & $\because 0$ & $* 1 .+7$ & القيادات الوسطى & \multirow{2}{*}{ القيادات } & \multirow{2}{*}{ المستفيلين على } \\
\hline القيادات العليا & $\because \cdot 0$ & $* 1.1 \mathrm{r}$ & القيادات التنفيذية & & \\
\hline القيادات العليا & $\because .0$ & $* 1 . r \Lambda$ & القيادات الوسطى & \multirow{2}{*}{ القيادات العليا } & \multirow{2}{*}{ التأثير على التمع } \\
\hline القيادات العليا & $\because \cdot 0$ & $* 1 . \cdot v$ & القيادات التنفيذية & & \\
\hline القيادات العليا & $\because \cdot 1$ & $* Y . I V$ & القيادات الوسطى & \multirow{2}{*}{ القيادات } & \multirow{2}{*}{ نتائج الأداء } \\
\hline القيادات العليا &.$\cdot 1$ & * ו & القيادات التنفيذية & & \\
\hline القيادات العليا & $\because \cdot 1$ & $* 11.9$. & القيادات الوسطى & \multirow{2}{*}{$\begin{array}{l}\text { القيادات } \\
\text { العليات }\end{array}$} & \multirow{2}{*}{ للاححور الثاني } \\
\hline القيادات العليا &.$\cdot 1$ & *r.r.r & القيادات التنفيذية & & \\
\hline
\end{tabular}

يظهر من الجدول (^) أن اتجاه دلالة الفروق يكون لصالح القيادات العليا، أي عينة الدراسة من القيادات العليا للتعليم ترى بصورة أوضح من غيرها من القيادات في وجود تميز مؤسسي قوي بإدارة تعليم الطائف. 
ولم يقف الباحث على دراسة من الدراسات السابقة التي تناولت التميز المؤسسي والمعروضة في محور الدراسات السابقة من أدبيات الدراسة- تناولت الفروق في تقييم درجة تحقيق التميز المؤسسي وفقاً لمتغير الموقع القيادي لعينة الدراسة، وهو الأمر الذي يجعل

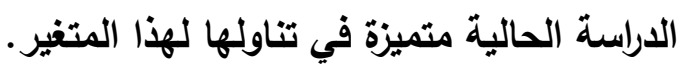
ويعزو الباحث النتيجة الحالية في دلالتها على وجود فروق في استجابات عينة الاراسة في درجة تحقيق التميز المؤسسي حسب الموقع القيادي لعينة الدراسة، إلى ما سبقت فئه الإثارة إليه عند تناول واقع تطبيق إدارة المعرفة من أن القيادات العليا هي المنوط بها بالدرجة الأولى تحقيق هذا الأمر، وهي ترى أنها بذلت الجهود المناسبة في هذا الأمر، وإن كان هناك المزيد لبذله، أما القيادات الوسطى والتنفيذية، فبحكم قريهما من الواقع، فقد أدركا درجة تحقيق التميز المؤسسي بشكل مغاير عن إدراك القيادات العليا له، وذلك في كل من الأبعاد واللارجة الكلية للمحور الثاني للاستبانة، فجاعت استجابات هاتين الفئتين في تقييمهما لارجة تحقيق التميز المؤسسي بدرجة أقل من تقييم القيادات العليا. (ץ) حساب دلالة الفروق بين متوسطات استجابات أفراد عينة الاراسة على المحور الثاني من الاستبانة طبقاً لمتغير (المؤهل العلمي):

حيث استخدام اختبار (ت) T-test لتحديد دلالة الفروق وفق متغير المؤهل العلمي. جدول (9) نتائج اختبار (ت) لدلاية الفروق بين استجابات عينة الدراسة على المحور الثاني

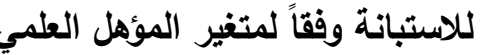

\begin{tabular}{|c|c|c|c|c|c|c|c|}
\hline الإحصائية & قيمة & الحرجة & الالحيراف & المستوسطي & العدد & المجموعات & البعد البع \\
\hline \multirow[b]{2}{*}{$\because+1$} & \multirow[b]{2}{*}{ Y.VI } & \multirow[b]{2}{*}{ rq } & 2.75 & 11.92 & TYY & بكالوريوس & \multirow[b]{2}{*}{ القيادة الإدارية } \\
\hline & & & 3.00 & 12.92 & $v_{1}$ & البكالوريوس من & \\
\hline \multirow[b]{2}{*}{$\because \cdot 1$} & \multirow[b]{2}{*}{$r . \cdot 1$} & \multirow[b]{2}{*}{ rq } & 2.80 & 12.57 & rYr & بكالوريوس & \multirow{2}{*}{ والاستراتيجيات } \\
\hline & & & 3.00 & 13.69 & $v_{1}$ & البكالوريوس من & \\
\hline \multirow[b]{2}{*}{$\because 0$} & \multirow[b]{2}{*}{$r . \cdot r$} & \multirow[b]{2}{*}{ rq } & 2.78 & 11.36 & TrY & بكالوريوس & \multirow[b]{2}{*}{ الموارد البشرية } \\
\hline & & & 2.84 & 12.10 & vi & البكالوريوس من & \\
\hline \multirow[b]{2}{*}{$\because \cdot 1$} & \multirow[b]{2}{*}{ r.v V } & \multirow[b]{2}{*}{ rq1 } & 2.81 & 11.28 & TrY & بكالوريوس & \multirow{2}{*}{ الشر اكة والموارد } \\
\hline & & & 3.11 & 12.32 & VI & البكالوريوس من & \\
\hline \multirow{2}{*}{ غير دالة } & \multirow{2}{*}{1.0.} & \multirow{2}{*}{ ral } & 3.36 & 13.89 & MYY & بكالوريوس & \multirow{2}{*}{ إدارة العمليات } \\
\hline & & & 3.27 & 14.55 & $\mathrm{VI}$ & أعلى من & \\
\hline
\end{tabular}


واقع تطبيق مضامين إدارة المعرفة في إدارة تعليم الطائف وعلاقته بالتميز المؤسسي من وجهة نظر القيادات العاملة بها.

\begin{tabular}{|c|c|c|c|c|c|c|c|}
\hline الإحصائية & قيمة & الحرجة & الالمعرافياري & الحتوسطابي & العدد & المجموعات & البعد \\
\hline & & & & & & البكالوريوس & \\
\hline \multirow[b]{2}{*}{ غير دالة } & \multirow[b]{2}{*}{.$\wedge 1$} & \multirow[b]{2}{*}{ rql } & 3.13 & 13.89 & MYr & بكالوريوس & \multirow[b]{2}{*}{ الإدارة الإكترونية } \\
\hline & & & 3.31 & 14.23 & VI & أبكالوريوس من & \\
\hline \multirow{2}{*}{ غير دالة } & \multirow[b]{2}{*}{$1.0 \mathrm{~V}$} & \multirow[b]{2}{*}{ rq1 } & 2.17 & 8.21 & TrY & بكالوريوس & \multirow{2}{*}{ التركيز على الميدين } \\
\hline & & & 2.22 & 8.66 & VI & ألبكالوريوس من & \\
\hline \multirow{2}{*}{ غير دالة } & \multirow[b]{2}{*}{1.0} & \multirow[b]{2}{*}{ rql } & 2.75 & 11.05 & TYY & بكالوريوس & \multirow{2}{*}{ التأثير على } \\
\hline & & & 3.07 & 11.61 & VI & البكالوريوس من & \\
\hline \multirow[b]{2}{*}{$\because 0$} & \multirow[b]{2}{*}{ r.rY } & \multirow[b]{2}{*}{ rql } & 3.75 & 15.26 & rrr & بكالوريوس & \multirow{2}{*}{ نتائج الأداء } \\
\hline & & & 3.83 & 16.41 & VI & ألبكالوريوس من & \\
\hline \multirow[b]{2}{*}{$\because 0$} & \multirow[b]{2}{*}{$Y . \leqslant \Lambda$} & \multirow[b]{2}{*}{ rql } & 21.63 & 109.45 & TrY & بكالوريوس & \multirow{2}{*}{ للالمحور الثاني الكلية } \\
\hline & & & 21.79 & 116.48 & VI & أبكالوريوس من & \\
\hline
\end{tabular}

يتبين من الجدول (9) السابق ما يلي: وجود فروق ذات دلالة إحصائية عند مستوى

(التميز المؤسسي)، عدا الأبعاد (إدارة العمليات، الإدارة الإكترونية، التركيز على المستقيدين، التأثير على المجتمع) ولكون متوسط فئة الحاصلين على مؤهل أعلى من بكالوريوس أكبر من متوسط فئة الحاصلين على بكالوريوس، فإن اتجاه الفروق في درجة واقع تطبيق إدارة المعرفة يكون لصالح فئة الحاصلين على مؤهل أعلى من بكالوريوس. ويعزو الباحث النتيجة الحالية في دلالتها على وجود فروق ذات دلالة في استجابات عينة الدراسة على محور (التميز المؤسسي) وفقاً لمتغير المؤهل العلمي إلى ما سبقت الإشارة إليه من أنه مع الارتقاء بالمستوى التعليمي للقيادات التربوية فإنها تدرك الواقع

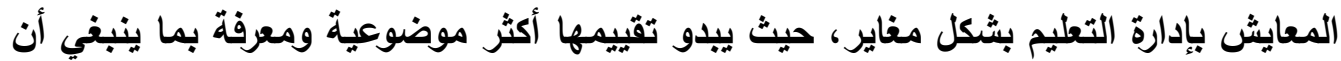
يكون تجاه تطبيق إدارة المعرفة في إدارة تعليم الطائف، وترتب على ذلك أن تباعدت استجابات عينة الدراسة على المحور الثاني للاستبانة (الأبعاد والارجة الكلية) بالثكل الذي الذي كشف عن وجود فروق حقيقية بينها، ومن ثَُّّ جاءت قيمة (ت) للفروق بين مجموعتي الاراسة طبقاً للمؤهل العلمي دالة إحصائياً. 
أما الأبعاد التي جاعت الفروق فيها غير دالة إحصائياً، فإنه يتبين أن هذه الأبعاد ترتبط بمتغيرات قائمة في الواقع لا يختلف تقييمها باختلاف المستوى التعليمي للمقييمين، فالإدارة الإكترونية تتميز بتوفر بينة تحتية مناسبة، وهو ما ياركه جميع القيادات في الواقع باتع حيث التطور في مصادر التعلم في كل مدرسة وإدارة، وكذلك التأثثر على المجتمع أو لإدئ

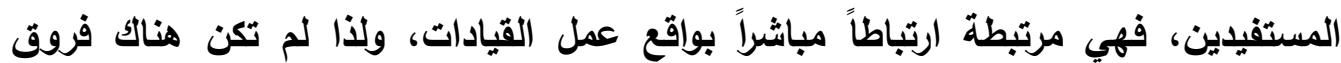
حقيقية في تقييمها.

النتائج المتعلقة بالسؤال الخامس ومناقشتها وتفسيرها: والذي ينص على: "ما طبيعة العلاقة الارتباطية بين واقع إدارة المعرفة وتحقيق التميز المؤسسي بإدارة التعليم بالطائف "؟ وللإجابة على هذا السؤال، تم حساب مصفوفة معاملات الارتباط بين المحور الأول للاستبانة (واقع تطبيق إدارة المعرفة) وما تضمنه من أبعاد (ع أبعاد)، وبين المحور الثاني

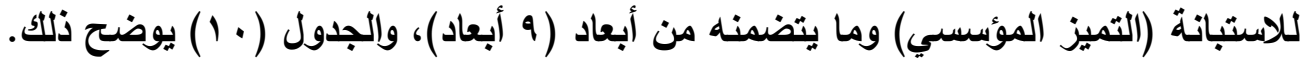

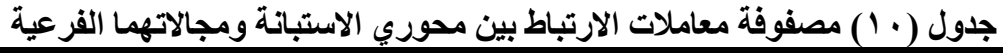

\begin{tabular}{|c|c|c|c|c|c|c|}
\hline \multirow{2}{*}{ للمحور الأول } & \multicolumn{4}{|c|}{ واقع تطبيق إدارة المعرفة } & \multicolumn{2}{|l|}{ المحور الأول } \\
\hline & تطبيقي & المعرفة & تحزينة & إلتاج وتوليد & & \\
\hline$* * . . V r$ & $* * . . V 1$ & $* * . .71$ & $* * .0 \leq$ & $* * . .7 V$ & القيادة الإدارية & \multirow{9}{*}{ المؤسسيز } \\
\hline$* * .7 \leqslant$ & $* * . .74$ & $* * .71$ & $* * . . \leqslant 1$ & $* * . .7$ & والاسيتراتيجيات & \\
\hline$* * . . V Y$ & $* * . . V$. & $* * . .74$ & $* * . .07$ & $* * .71$ & الموارد البشرية & \\
\hline$* * . . \mathrm{V} \theta$ & $* * . .7 V$ & $* * . .71$ & $* * \cdot .7 \varepsilon$ & $* * . .71$ & الثر اكة والموارد & \\
\hline$* * . .79$ & $* * . .70$ & $* * ., \Gamma \varepsilon$ & $* * .0 \leqslant$ & $* * . .70$ & إدارة العمليات & \\
\hline$* * \cdot . \mu \cdot$ & $* * . r v$ & $* * . .71$ & $* * \cdot Y I$ & $* * . Y 4$ & الإدارة الإكترونية & \\
\hline$* * . .77$ & $* * . .7$ & $* * .0 \leqslant$ & $* * . .7$ & $* * .74$ & المستفيزين على & \\
\hline$* * . . V \leq$ & $* * . .71$ & $* * . .70$ & $* * . .7 \leq$ & $* * . .71$ & التجتئمير على & \\
\hline$* * . .0 \leqslant$ & $* * . .0 \mathrm{~V}$ & $* * . .0 Y$ & ד & $* * .01$ & نتائج الآداء & \\
\hline$* * . . \vee \wedge$ & $* * . . \vee 0$ & $* * \cdot . v 1$ & $* * . .7$. & $* * \cdot V Y$ & لية للمحور الثاني & |لارجة || \\
\hline
\end{tabular}

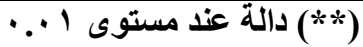

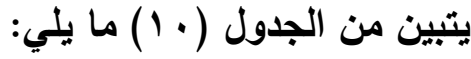


ا- وجود علاقة ارتباطية دالة وموجبة بين المحور الأول للاستبانة (واقع تطبيق إدارة المعرفة) وما تضمنه من أبعاد (ع أبعاد)، ويين المحور الثاني للاسنبانة (التميز

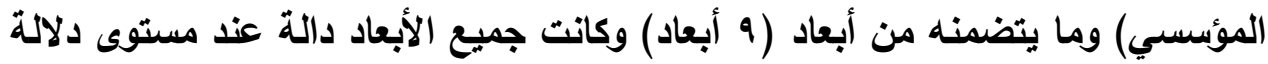

$$
(\cdot .1)
$$

r - أن أقوى المعاملات كاتت بين الدرجة الكلية لتطبيق إدارة المعرفة ويين الدرجة الكلية

$$
\text { للتميز المؤسسي، ثم أبعاده. }
$$

ويرى الباحث أن تطبيق إدارة المعرفة في المؤسسات التريوية يعمل على نشر ثقافة إيجابية نحو التغيير والتظور، ومن ثمَّ تعمل عمليات التطور بانسيابية ويدون أي عوائق تحول بينها ويين الوصول للتغير المنشود، ويذلك يسهل تحقيق التميز المؤسسي بهذه المؤسسات.

كما يعمل التميز المؤسسي إلى نشر المعرفة وامتلاك أدواتها، وتطبيق كافة البرامج الخاصة بها، ويذلك يسهم التميز المؤسسي في رفع درجة ومعدل تطبيق إدارة المعرفة. أي أن العلاقة بين التميز المؤسسي وتطبيق إدارة المعرفة علاقة تبادلية في ظل ما كشفت عنه النتائج الحالية.

\section{توصيات الدراسة}

1. حث القائمين على إدارة تعليم الطائف على تطوير تطبيقهم لإدارة المعرفة من حيث: تثارك المعرفة مع الجهات المجتمعية، وإنتاج وتوليد المعرفة داخل مؤسساتها، وتخزين المعرفة وتطبيقها، بما يحقق تطبيقاً متميزاً لإدارة المعرفة بهذه المؤسسات. r. العمل مع الجهات المسؤولة على تخصيص ميزانية لاعم عمليات توليد المعرفة (من: شراء أو ابتكار أو اكتساب)، وكذلك توفير الآليات والوسائل المختلفة لإتاحة (الفرصة للعاملين على اكتساب معارف جديدة وصقلها ومعالجتها بما يسهم إيجابياً في إنتاج وتوليد المعرفة

r. حث المسؤولين على مراجعة أوعية خزن المعرفة بشكل دوري يضمن سلامتها من التلف أو الفقان، مع التزام الدقة والمرونة في عملية خزن واسترجاع المعلومات والبيانات، بما يؤدي إلى تجويد إجراءات تخزين المعرفة. 
واقع تطبيق مضامين إدارة المعرفة في إدارة تعليم الطائف وعلاقته بالتميز المؤسسي من وجهة نظر القيادات العاملة بها.

ع. العمل على متابعة الوسائل والأنظمة والسياسات التي تنقل المعرفة بشكل واضح ومفهوم للعاملين بها، وكذلك تسهيل عمليات التواصل بين العاملين وبين الخبراء والمختصين، وذلك على النحو الذي يؤدي إلى تفعيل تشارك المعرفة بشكل حقيقي. ه. العمل على توفير خطط طوارئ لحل الأزمات والمشكلات التي تمر بها إدارة التعليم، وكذلك

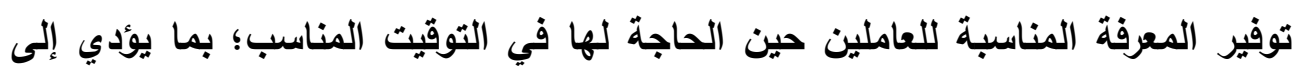
تطبيق فعال لإدارة المعرفة يشعر به كافة العاملين بهذه الإدارة. 


\section{مراجع الدراسلة:}

\section{أولأُ المراجع العربية.}

أبو النادي، مريم فؤاد (9 . . ب). قواعد مقترحة لإدارة المعرفة في الجامعات الأردنية الرسمية بناء على نماذج مقترحة. رسالة دكتوراه، الجامعة الأردنية.

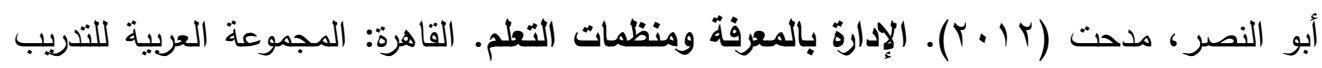
والنشر

أبو حطب، أنشرف سالم (10 • ( ). درجة ممارسة مديري مدارس وكالة الغوث بمحافظات غزة للتخطيط الاستراتيجي المدرسي وعلاقتها بمستوى ادارة المعرفة. رسالة ماجستير ، كلية التربية، الجامعة دائه الإسلامية بغزة.

أبو علام، محمود رجاء (• ( • ). الإحصاء في العلوم التربوية. طج، القاهرة: مكتبة الفكر العربي.

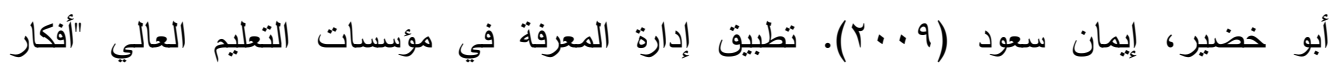

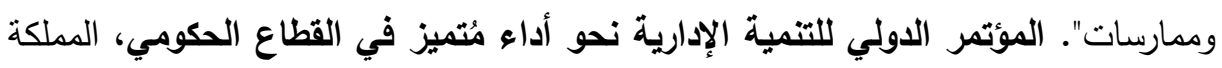

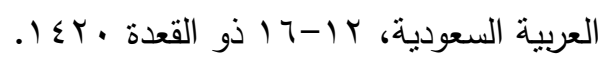

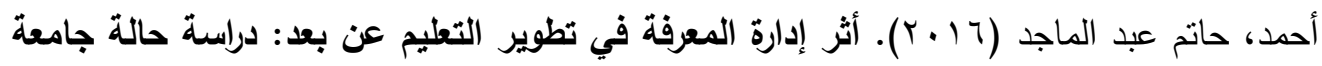

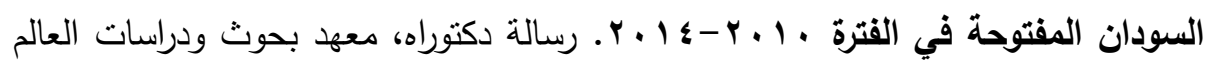

$$
\text { الإسلامي، جامعة أم درمان الإسلامية. }
$$

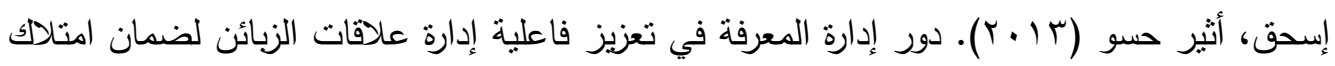

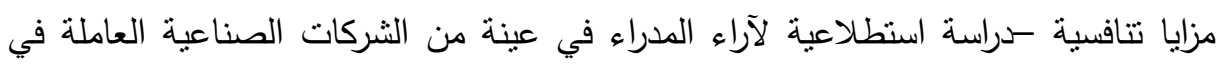

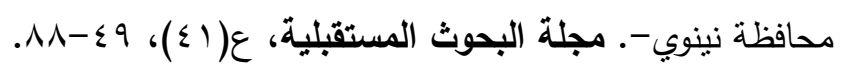

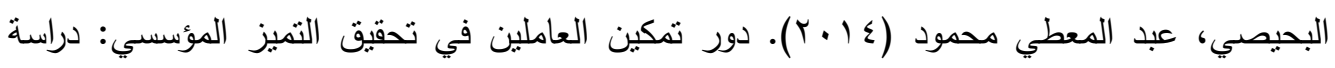

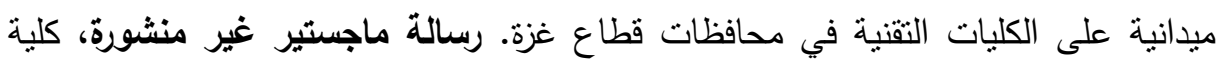
الاقتصاد والعلوم الإدارية، جامعة الأزهر بغزة، فلسطين.

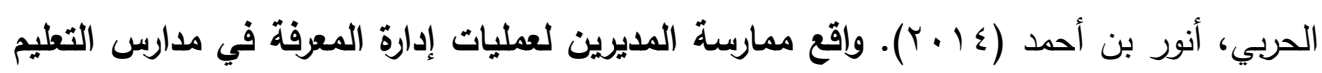
العام بينبع. رسالة ماجستير ، كلية التربية، جامعة طيبة.

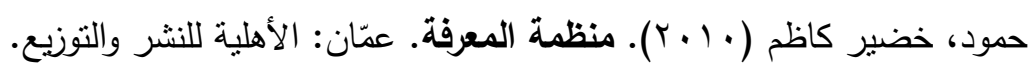

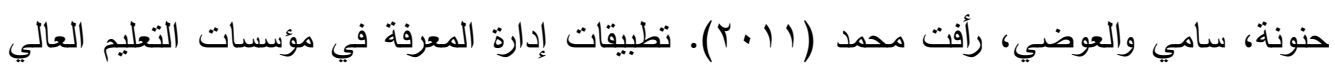

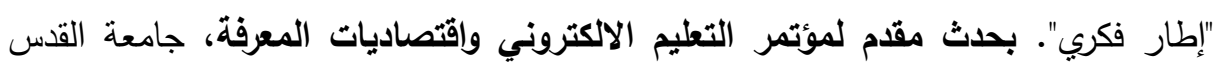

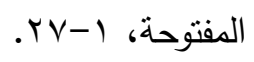


الخليفة، محمد الجيلاني أحمد (10 ب ب). أثر إدارة المعرفة على الاداء المؤسسي في المنشأة

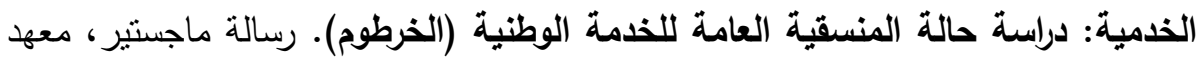

$$
\text { بحوث ودراسات العالم الإسلامي، جامعة أم درمان الإسلامية. }
$$

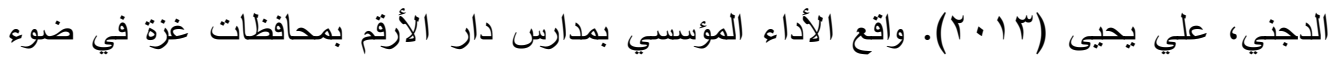

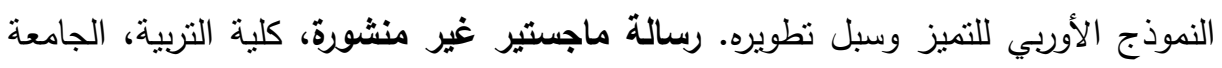
الإسلامية بغزة.

الدويسمية، دهند مولود (T 1 ب ب). أثز الإدارة الاستراتيجية للموارد البشرية على التميز المؤسسي

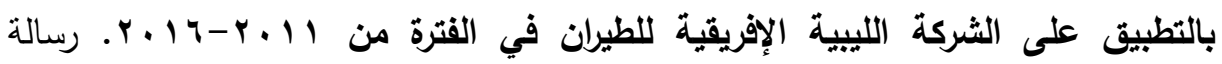

$$
\text { ماجستير ، كلية الدراسات العليا، جامعة أم درمان الاسلامية العبدية }
$$

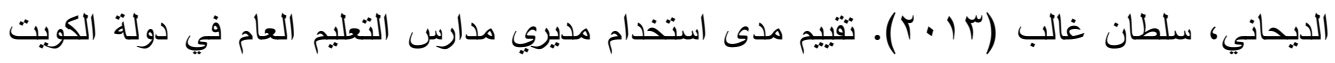
لمهارات إدارة المعرفة و أساليب اتخاذ القرار ـ مجلة دراسات الخليج والجزيرة العربية (الكويت)

$$
.11 \mathrm{~V}-10 \text { ، (1 ( } \leqslant \Lambda) \mathrm{rq} \text { ، }
$$

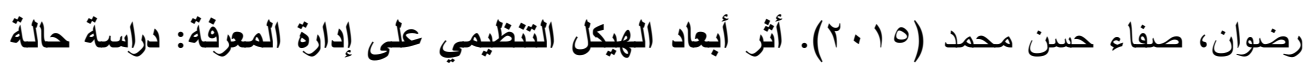

وزارة الثؤون الاجتماعية. رسالة ماجستير ، كلبة التجارة، الجامعة الإسلامية بغزة.

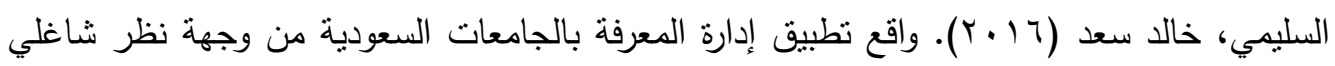

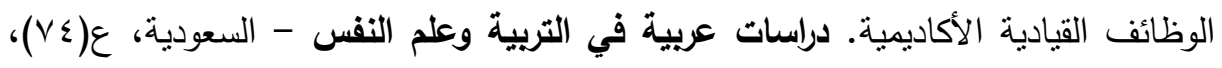

$$
\text { rOI - r T R }
$$

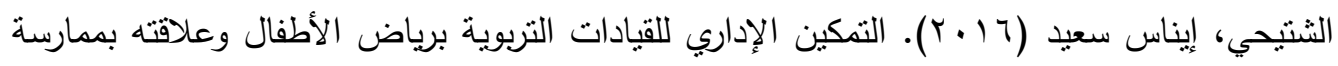

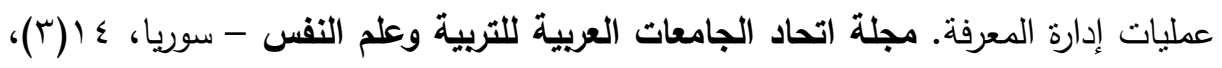

$$
\text { .1. } 1 \text { - } \leqslant r
$$

الثريف، طلال عبداله (7 ( • Y). واقع تطبيق إدارة المعرفة في ضوء التحولات المعاصرة في الجامعات

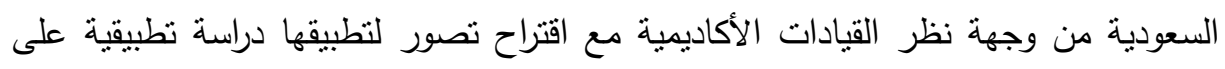
جامعات (أم القرى، الملك عبد العزيز ، الطائف، الباحة). مجلة كلية التربية ( جامعة بنها )

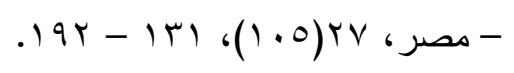

الثهري، سعد غازي (10 • (10). منطلبات تطبيق إدارة المعرفة في الددارس الثانوية بإدارة تعليم محايل

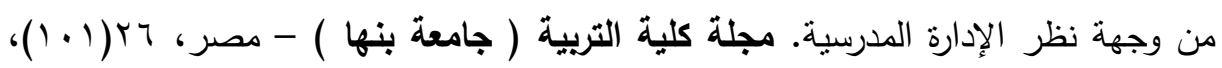
- 199 
الثوملى، سهير إبراهيم (T ( • Y). إدارة المعرفة و أثزها على أداء الهيئة التدريسية في جامعة فلسطين التقنية خضوري. أبحاث المؤتمر العلمي الدولي حول : الإبداع والإبتكار في منظمات

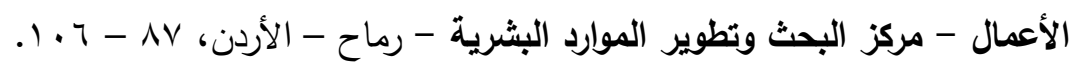

عايل، حسن، (Y ( ا r): برنامج مقترح في أساليب التعلم الذاتي لتحقيق التعليم المستمر في ضوء اقتصاد المعرفة لطلاب كليات التربية في المملكة العربية السعودية، مجلة العلوم التريوية، بحوث المؤتمر العلمي (التعليم المستمر وتحديات مجتمع المعرفة)، كلية التربية، جامعة

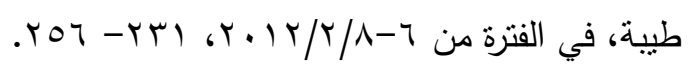

عبد الهادي، أميره رمضان (10 (r). إدارة المعرفة كمدخل لتحقيق الميزة التنافسية بالجامعات المصرية. مجلة الإدارة التريوية- الجمعية المصرية للتربية المقارنة والإدارة التعليمية -

$$
\text { مصر، }
$$

عبيدات، شروق حسن (T ( ب). أثر إدارة المعرفة على وظائف الموارد البشرية في الشركات الصناعية الأردنية المساهمة العامة. رسالة ماجستير ، كلية الأعمال، جامعة عمّان العربية.

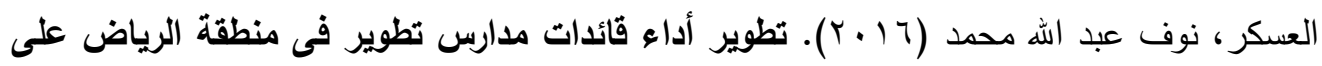
ضوء آليات إدارة المعرفة. رسالة ماجستير، كليات الثرق العربي للاراسات العليا، الرياض. القتامي، عزيز معوض (عبء اهـ). تطبيق إدارة الجودة الثاملة في الإدارة العامة للتزبية والتعليم بمحافظة الطائف: الإمكانيات والمعوقات من وجهة نظر العاملين فيها. رسالة ماجستير غير منشورة، كلية التربية، جامعة ام القرى.

كامل، جنان حاتم (0 (ب). إدارة عمليات المعرفة لدى مديري ومديرات مدارس المتميزين والمتميزات

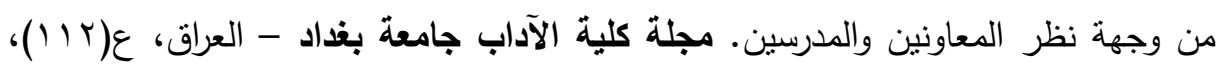

$$
.017-\leqslant 09
$$

الكبيسي، صلاح الدين (ع ( ب). إدارة المعرفة. طب، القاهرة: المنظمة العربية للتمية الإدارية. مال الله عبدالرحمن حسين، وعطية، رعد (r ( r). إستراتيجية إدارة المعرفة و علاقتها بالمهارات

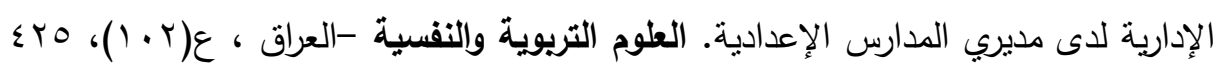

$$
\leq 9 \leq-
$$

النسور ، أسماء سالم (· ( • ( ). أثر خصائص المنظمة المتعلمة في تحقيق التميز المؤسسي دراسة تطبيقية في وزارة التعليم العالي والبحث العلمي الأردنية. رسالة ماجستير، كلية الأعمال،

$$
\text { جامعة الثرق الأوسط. }
$$

نصير، مبروك محمد السيد (10 ( ا). إطار مقترح لإدارة التغيير وتطوير الادارة الضريبية نحو تحقيق الجودة والتميز المؤسسي: بالتطبيق على مصلحة الضرائب المصرية. المؤتمر الضريبي 
واقع تطبيق مضامين إدارة المعرفة في إدارة تعليم الطائف وعلاقته بالتميز المؤسسي من وجهة نظر القيادات العاملة بها.

الثاني والعشرين بعنوان: تطوير النظام الضريبي المصري في ضوء متطلبات الاستثمار

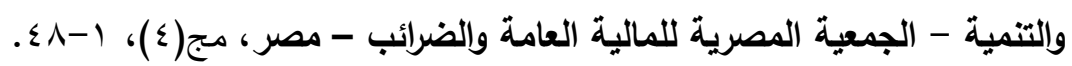

وزارة التعليم (جr؟اهـ). جائزة التعليم للتميز: الاليل التفسيري لمعايير التميز الإداري. الرياض: مطبوعات وزارة التعليم. ماك.

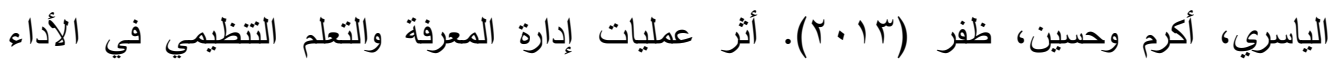
الاستراتيجي دراسة استطلاعية لآراء عينة من القيادات الإدارية في جامعات الفرات الأوسط.

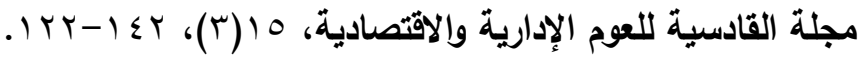

\section{ثانياً : المراجع الأجنبية.}

Costa, R. (2012). Assessing Intellectual Capital efficiency and productivity: An application to the Italian yacht manufacturing sector. Expert Systems with Applications, 39(8), 7255-7261.

Cristina, Mele\& Colurcio, Maria (2006). the evolving path of TQM: towards business excellence and stakeholder value. International Journal of Quality \& Reliability Management, 23(5), 464-489. 